\title{
Green Synthesis of Gold and Silver Nanoparticles from Plant Extracts and Their Possible Applications as Antimicrobial Agents in the Agricultural Area
}

\author{
Luis Castillo-Henríquez ${ }^{1}{ }^{\circledR}$, Karla Alfaro-Aguilar ${ }^{2}$, Jeisson Ugalde-Álvarez ${ }^{1}{ }^{\circledR}$, \\ Laura Vega-Fernández ${ }^{2}$, Gabriela Montes de Oca-Vásquez ${ }^{1}$ and José Roberto Vega-Baudrit ${ }^{1,2, *(D)}$ \\ 1 National Laboratory of Nanotechnology (LANOTEC), National Center for High Technology (CeNAT), \\ San José 1174-1200, Costa Rica; luis.castillohenriquez@ucr.ac.cr (L.C.-H.); jei.ugalde@gmail.com (J.U.-Á.); \\ gmontesdeoca@cenat.ac.cr (G.M.d.O.-V.) \\ 2 Chemistry School, National University of Costa Rica, Heredia 86-3000, Costa Rica; \\ karla.alfaro30@gmail.com (K.A.-A.); laly.vega@hotmail.com (L.V.-F.) \\ * Correspondence: jose.vega.baudrit@una.cr
}

Received: 12 July 2020; Accepted: 26 August 2020; Published: 7 September 2020

check for updates

\begin{abstract}
Currently, metal nanoparticles have varied uses for different medical, pharmaceutical, and agricultural applications. Nanobiotechnology, combined with green chemistry, has great potential for the development of novel and necessary products that benefit human health, environment, and industries. Green chemistry has an important role due to its contribution to unconventional synthesis methods of gold and silver nanoparticles from plant extracts, which have exhibited antimicrobial potential, among other outstanding properties. Biodiversity-rich countries need to collect and convert knowledge from biological resources into processes, compounds, methods, and tools, which need to be achieved along with sustainable use and exploitation of biological diversity. Therefore, this paper describes the relevant reported green synthesis of gold and silver nanoparticles from plant extracts and their capacity as antimicrobial agents within the agricultural field for fighting against bacterial and fungal pathogens that can cause plant, waterborne, and foodborne diseases. Moreover, this work makes a brief review of nanoparticles' contribution to water treatment and the development of "environmentally-friendly" nanofertilizers, nanopesticides, and nanoherbicides, as well as presenting the harmful effects of nanoparticles accumulation in plants and soils.
\end{abstract}

Keywords: agricultural industry; antibacterial; antimicrobial; green synthesis; gold; nanobiotechnology; nanoparticles; silver; sustainable development

\section{Introduction}

Green chemistry has been developed as an alternative to the use of environmentally harmful processes and products due to the serious consequences that the world is facing and the limited available time to find effective solutions [1-3]. According to Menges, it is suggested that green chemistry could have saved USD 65.5 billion by the end of 2020 [4].

Chen et al. stated that circular economies (i.e., an economy that gradually decouples economic activity from finite resources consumption) should always aim to balance economic growth, resource sustainability, and environmental protection [5]. The challenge for biodiversity-rich countries and scientists working in these countries is to collect and convert knowledge from biological resources into processes, compounds, methods, and tools, which need to be achieved along with sustainable use and exploitation of biological diversity [6-8]. In addition to that, biodiversity exploration has been presented to the international scientific community as a promoter of the responsible use of nature, and as a means of obtaining non-harmful components as well. For this reason, different strategies 
have been sought to contribute to this field through the use of green processes, such as the creation of nanoparticles (NPs) from plant extracts [9-11].

NPs are a wide range of materials with dimensions below $100 \mathrm{~nm}$, which can be used in various applications, such as medical, pharmaceutical, manufacturing and materials, environmental, electronics, energy collection, and mechanical industries, due to their multiple properties [12-15]. In general, NPs can be found as carbon nanotubes, quantum dots, nanorods, nanocapsules, nanoemulsions, fullerenes, metallic NPs, ceramic NPs, and polymer NPs $[15,16]$. Regarding the metallic NPs, their outstanding properties have caused the development of different methodologies for their synthesis, where gold $\mathrm{(Au}$ ) and silver $(\mathrm{Ag})$ NPs prepared from plant extracts are of great interest for the researchers in their attempt to develop suitable antimicrobial agents for agriculture [17-20]. Besides, these initiatives are considered as low-cost processes that allow avoiding toxic-generating products and benefit the agricultural activity. It is estimated that the preparation of one $\mathrm{kg}$ of silver nanoparticles (AgNPs) would cost about USD 4 million, while one $\mathrm{kg}$ of raw Ag costs around USD 14,000 [21,22].

In 2009, Raveendran et al. published one of the first green synthesis methods of metal NPs. They employed an aqueous starch solution subjected to heating, silver nitrate $\left(\mathrm{AgNO}_{3}\right)$, and glucose as the green reducing agent [23]. After that, researchers like Iravani and Kumar et al. presented high-quality review papers regarding the synthesis of metallic NPs using plant extracts as a green chemistry approach $[24,25]$. Since then, the synthesis of metal NPs has been performed by different research groups based on a variety of plants and their structures. Logeswari et al. developed an eco-friendly synthesis of AgNPs from plant powders of Solanum tricobatum, Syzygium cumini, Centella asiatica, and Citrus sinensis, while Yang et al. biosynthesized gold nanoparticles (AuNPs) using an agricultural waste mango peel extract [26,27]. Verma et al. and Bagherzade et al. showed the antimicrobial activity of metal NP obtained through green synthesis using Azadirachta indica leaves and Crocus sativus L. extracts, respectively [28,29].

Due to the nanotechnological boom, unusual physical, chemical, and biological methods have been developed for the synthesis and production of metal NPs [30-35]. Therefore, the novelty of this paper lies in describing the relevant reported green synthesis of AuNPs and AgNPs from plant extracts and their capacity as antimicrobial agents within the agricultural field for fighting against bacterial and fungal pathogens that can cause plant, waterborne, and foodborne diseases. Moreover, this work makes a brief review of AuNPs and AgNPs' contribution to water treatment and the development of "environmentally-friendly" nanofertilizers, nanopesticides, and nanoherbicides, as well as describing the harmful effects of NPs accumulation in plants and soils.

\section{Methods for Obtaining Plant Extracts}

Extraction methods are the first step for the separation of plant metabolites from the raw materials. In order to carry out an extraction process, some basic parameters need to be considered since these influence the quality of an extract [36]. The extraction of the interest components is largely dependent on the selected part from the plant material, as well as the solvents, which need to exhibit ease of evaporation, and the inability to chemically modify the solutes. Since the final product will retain traces from the employed solvent, the latter must have low toxicity. Additionally, selecting an extraction method involves addressing the length of extraction, temperature, solvent's $\mathrm{pH}$, solvent-to-sample ratio, and particle size of the raw materials. These factors can induce variations in the metabolite composition of the extracts [37].

The main extraction methods for the synthesis of AuNPs and AgNPs are (a) solvent-based extraction, (b) microwave-assisted extraction, and (c) maceration extraction [38]. However, ultrasound-assisted extraction is an important alternative to improve process efficiency. The ideal extraction method should be cost-effective, simple, less time-consuming, and carried out with ease in any laboratory [39]. 


\subsection{Solvent-Based Extraction}

This is the most widely used method for obtaining natural products. This method separates plant soluble metabolites using a suitable solvent and discards the insoluble materials [40]. Before starting, it is important to have information about the plant properties, such as the particle size of the raw materials and constituent components to select a proper solvent for the extraction. Besides, defining solvent-to-solid ratio, extraction temperature, and the time required for the process are also important. Factors that enhance the diffusion and solubilization of the solutes can increase the efficiency of the experiment [41]. The extraction process follows several stages, where initially the solvent penetration into the solid matrix is necessary to establish interactions with the available surface. Later, the solute must diffuse out of the solid matrix to collect it [42].

Recently, the application of green solvents (e.g., ethyl lactate and ionic liquids) has caught attention in different disciplines. These solvents are seen as non-toxic, biocompatible, and biodegradable alternatives to the conventional ones. In addition to that, they are easier to prepare and are cost-effective. Some advances regarding green solvent technologies are deep eutectic solvents (DESs), natural deep eutectic solvents (NDESs), ionic liquids (ILs), surfactants, and bio-derived solvents [43,44].

\subsection{Microwave-Assisted Extraction}

Microwave energy is employed for the partition of analytes from the sample into the solvent. This is caused by rapid heating due to the interaction with polar and polarizable compounds, such as water and the ones present in the plant matrix sample. In these, process heat is transferred by conduction, allowing materials to reach the necessary level of energy [38,45]. In addition to that, heat and mass transfer occur in the same direction, which results in a synergistic effect that accelerates and improves the recovery of analytes. Therefore, its implementation reduces the extraction time and solvent volume compared to other methods [46]. Aside from that, studies have shown other advantages, such as increasing the extract yield and selective heating of vegetal material [47].

Moreover, there are two variants for this method. Solvent-free extraction is usually employed for volatile compounds, while the solvent-based technique is recommended for non-volatile substances. Nevertheless, it is necessary to take into consideration two important aspects. In the first place, special concerns have to be foreseen for preventing samples' thermal degradation, and second, this method is mostly limited to small-molecule phenolic compounds [48].

\subsection{Maceration Extraction}

This process can be achieved by following three basic steps: (a) grinding the plant in small pieces, (b) adding the appropriate solvent in a closed vessel, which will determine the type of compound that is going to be extracted from the sample, allowing soaking for three days at room temperature, and (c) press or strain by filtration to separate the liquid phase [49,50]. Although this may be considered the easiest and simplest method, the requirement of large volumes of organic solvents generates organic wastes that have become an issue, makingnecessarya proper chemical waste management process [51]. In addition to that, this conventional method for natural product extraction takes a long time, showing low extraction efficiency. The process intends to soften and break the raw material's cell wall to propitiate the release of soluble phytochemicals. However, its use for extracting thermolabile components can be seen as an advantage [52].

\subsection{Ultrasound-Assisted Extraction}

Usually called ultrasonification, this method exhibits multiple advantages over other techniques, such as low energy consumption, less solvent required, lower temperatures and extraction times. This method is considered one of the easiest plant extraction techniques because it requires a smashed sample placed in an ultrasonic bath with a suitable solvent. It uses ultrasonic wave energy (20-2000 kHz) for extracting natural compounds from raw material, increasing the surface contact between the solvent 
and the sample [52]. Ultrasound enhances the solvent's ability to penetrate the cells, which improves the efficiency of the process by disrupting the physical and chemical properties of the sample. Its influence on the solvent accelerates the dissolution and diffusion of the solute, facilitating the release of compounds. The method represents a cost-effective alternative for the scale-up of the industrial extraction of phytochemicals [53].

\section{Green Synthesis Methods of AuNPs and AgNPs from Plant Extracts}

Green chemistry is an emerging area that fosters the implementation of a set of principles intended to reduce the utilization and generation of chemical hazardous wastes [54]. As a result of that, green methods reduce the industrial labor impact on the ecosystem. Through their development, scientists are providing possible solutions to costly processes and hazardous materials encountered when using traditional physicochemical synthesis methods [55-58]. The employment of environment-friendly solvents and reagents, reducing high energy consumption methods, using non-toxic biomolecules, such as DNA, proteins, enzymes, carbohydrates, as well as plant extracts, allow synthesizing biocompatible metallic NPs by reducing metal ions in aqueous solutions [59,60].

AuNPs and AgNPs are considered noble metal NPs (i.e., metals resistant to corrosion and oxidation) and have caught the attention due to their unique physicochemical and biological properties [61,62]. These metal NPs have attractive attributes, such as high electrical and thermal conductivity, chemical stability, high catalytic activity, and the most relevant for agriculture-the antimicrobial activity against a wide diversity of microorganisms. These characteristics have a close relation to their nanosized particles, tunable shape, and surface morphology [61].

According to Jamklande et al., there are two kinds of synthesis methods for obtaining AuNPs and AgNPs, depending on the starting material for their preparation (Figure 1) [63]. In the first place, the top-bottom synthesis path is employed when raw material is at larger scales than the nano, forcing to break down its particles by grinding, milling, lithographic techniques, or thermal ablation. This particle size reduction techniques involve an enormous consumption of energy and can cause surface imperfections in NPs, resulting in significant effects on their physicochemical properties $[58,63,64]$. On the other hand, the bottom-up synthesis path, also known as the "self-assembly approach", involves chemical and biological methods where atoms grow in nucleation centers to form NPs. Biosynthesis of AuNPs and AgNPs is a cost-effective type of bottom-up approach that allows an important amount of NPs' formation in a short time. In this greener path, the obtained NPs possess minimum defects and present a homogenous chemical composition [63,65-69].

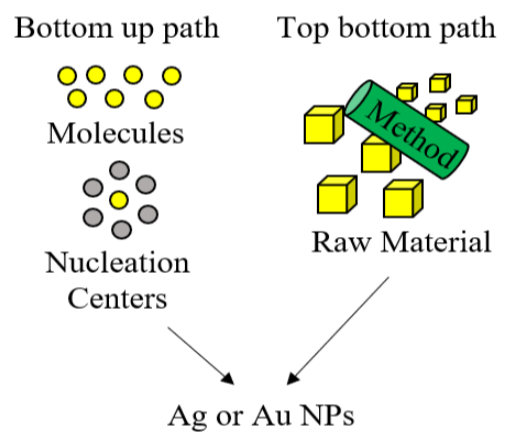

Figure 1. Synthesis of metal nanoparticles (NPs) from top-bottom and bottom-up paths [70].

The use of plant extracts is increasing in usefulness and is conceived as an environmentally and economically friendly alternative for the synthesis of AuNPs and AgNPs by several techniques, such as using $\mathrm{AgNO}_{3}$ or auric chloride $\left(\mathrm{HAuCl}_{4}\right)$ at room temperature within a few minutes to a couple of hours [65,71]. In addition to that, this synthesis method is faster compared to using bacteria or fungi [67]. Extracts can be obtained from multiple parts or products of the plant, such as leaves, bark, stem, shoots, seeds, latex, secondary metabolites, roots, twigs, peels, fruits, seedlings, essential oils, 
and tissues. They constitute a rich source of polyphenols, flavonoids, sugars, enzymes, and proteins. These phytochemicals are extracted and directly employed as reducing and stabilizing agents for the extracellular biosynthesis of metallic NPs, replacing potentially hazardous chemicals like sodium borohydride $\left(\mathrm{NaBH}_{4}\right)$ [61]. However, the specific mechanism for this phenomenon has not yet been elucidated due to the great variety of phytoconstituents present in the extracts. Although polyphenols, organic acids, and proteins are considered as the main reducing agents, it is expected that the different phytochemicals work synergistically [61]. In general, this method can represent a cost-effective suitable option for large-scale production processes [72].

Moreover, these unconventional synthesis methods of AuNPs and AgNPs have the advantage of producing large quantities of NPs that are free from contamination and possess better-defined size and morphology. Regarding their morphology, fabrication through plant extract-mediated synthesis results in NPs with a more energetically favorable spherical shape, which provides the necessary reactivity for different applications, including agricultural activity [73,74]. Four studies have reported the synthesis of spherical AgNPs through different extracts like the ones from Tribulus Terrestris fruit, Alternanthera dentate leaves, Acorus calamus roots, and Boerhaavia diffusa species whole plant [75-78].

Other studies have produced NPs from various plant extracts, where, also, differences in shape are expected to happen when using different structures from the same plant for the extraction process $[79,80]$. However, as reported by Rajakumar et al., the use of Eclipta prostrate leaves for AuNPs synthesis produced triangle, pentagon, and hexagon shapes [81]. A disadvantage of these methods is that raw material's nature limits the set of conditions under which they can be used, and this can impact NPs' formation. Therefore, it is necessary to provide well-defined specifications regarding temperature, $\mathrm{pH}$, metallic solution composition, and the reaction time as well [73].

Arreche et al. studied two commercial brands of yerba mate (Ilex paraguariensis) for the preparation of aqueous extracts to synthesize AgNPs at room temperature using $\mathrm{AgNO}_{3}$ (Figure 2). The obtained NPs were spherical, hexagonal, and triangular, with an average particle size of $50 \mathrm{~nm}$ and surface plasmon peak at $460 \mathrm{~nm}$. Additionally, the antimicrobial activity was evaluated against Escherichia coli and Staphylococcus aureus. The minimum inhibitory concentrations required for E. coli were 7.66 and $17.66 \mu \mathrm{g} \cdot \mathrm{mL}^{-1}$ using the treatment brand 1 and brand 2, respectively. On the other hand, the values for S. aureus were 23.25 and $50.60 \mu \mathrm{g} \cdot \mathrm{mL}^{-1}$ for the treatment brand 1 and brand 2 , respectively. The study suggests that polyphenols present in yerba mate leaf extract take action as a reducing agent and stabilizer of the NPs [82].
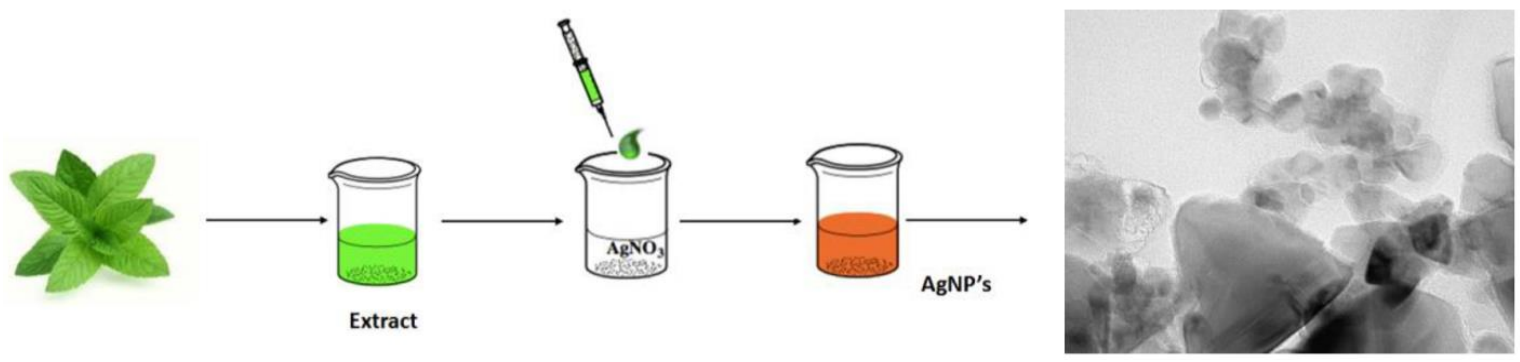

Figure 2. Synthesis of silver nanoparticles (AgNPs) using natural extracts from wastes.

Besides, Sasidharan et al. used the pericarp of Myristica fragans fruit extract for the eco-friendly synthesis of AgNPs. In this approach, the aqueous fruit extract of the plant fulfilled reducing and stabilizing functions for the preparation, and the obtained AgNPs exhibited good catalytic and antibacterial activities [83]. Alkhalaf et al. conducted a study to identify the effect of the green synthesis of AgNPs from a Nigella sativa plant extract, resulting in NPs that exhibit antioxidant activity [84].

On the other hand, different attempts have successfully synthesized AuNPs, as well, through the application of a green process. Kesarla et al. worked on a green synthesis method using an aqueous extract of a fine powder of Terminalia bellirica dry fruit pericarp, which performed reducing and stabilizing functions. The experiment required to add one gram of the powder to $100 \mathrm{~mL}$ of 
deionized water, heat and maintain the temperature at $90{ }^{\circ} \mathrm{C}$ for $1 \mathrm{~h}$, then cool and filter using a $0.2 \mathrm{~mm}$ cellulose nitrate membrane filter. After that, the freshly prepared extract was added to $2 \mathrm{~mL}$ of $\mathrm{HAuCl}_{4} 1 \mathrm{mM}$ and mixed vigorously. The synthesis occurred almost instantaneously, taking less than $10 \mathrm{~s}$ to obtain the NPs, inferred from the immediate color change from yellow to reddish pink. The rapid reduction and stabilization can be explained by the high levels of polyphenols in T. bellirica. Additionally, AuNPs' formation was confirmed by UV-Vis spectroscopy at $530 \mathrm{~nm}$ [85].

Some studies have synthesized and characterized both NPs. Sk et al. synthesized them using Malva Verticillata leaves' aqueous extract. AuNPs were found to have outstanding catalytic activity toward the hydride transfer reduction of the aromatic nitro Schiff bases, while AgNPs displayed interesting antibacterial activity [86]. Nadagouda et al. reported a great presence of phenolic compounds in turmeric extract, cyanides, and polyphenols in blueberry, pomegranate, and blackberry, which are responsible for the antioxidant activity and the formation of AuNPs and AgNPs [87].

\section{AuNPs and AgNPs Applications in Agriculture}

In general, the synthesis of NPs is of great interest because of their unique properties that can be incorporated into composite fibers, biosensor materials, cryogenic super-conducting materials, cosmetic products, and electronic components [88]. However, due to climate change and the depletion of natural resources, the synthesis of AuNPs and AgNPs from plant extracts, and even more by agricultural wastes, is a major topic for encouraging sustainable development in agro-industrial labors. Since plants are the basis of this green synthesis, the created NPs can be used in many agroindustry-related processes, from the application in the soil to the food chain, due to their low toxicity [89-91].

Nanotechnological food and agricultural applications were proclaimed in June 2009 in a joint venture of the Food and Agricultural Organization (FAO) and World Health Organization (WHO), with the inclusion of wide-ranging fields, such as nanostructured ingredients, nanosized biofortification, food packaging, nanocoating, and nanofiltration [92]. NPs may also act as "magic bullets", containing nutrients or other substances, such as beneficial genes, and organic compounds, which are targeted to specific plant areas or structures to enhance their productivity. Thus, NPs represent smart nano-delivery systems for agricultural administration, specifically on crop nutrition [93].

Regarding direct applications of AuNPs and AgNPs in agriculture, many pieces of researches on this field have been focused on seed germination, root elongation, and plant responses towards the presence of metal NPs, like cellular oxidative stress or cytotoxicity [89,94]. In addition to that, metal NPs can be employed for nano-fertilizers and nano-pesticides development [95]. Indirect applications based on the antimicrobial activity of the NPs are mostly related to food packaging [93]. The mentioned applications have been widely addressed in the agro-industries in a great variety of products containing NPs of these metals with a particle size that ranges from 100-250 nm, making them more soluble in water, and increasing their activity [96].

\subsection{Antimicrobial Properties}

Metal NPs from green synthesis can be used as antioxidants, biosensors, and for heavy metal detection as well [97-99]. In general terms, their unique physicochemical properties, such as their ability to bind biomolecules, large surface area to volume ratio, high surface reactivity, easy to synthesize and characterize, reduced cytotoxicity, and their capacity of enhancing gene expression for redox processes, allow using as antimicrobial agents against plant disease pathogens and others that can cause foodborne diseases [100-103]. A great variety of plant extracts used for generating AuNPs and AgNPs have been processed and reported their potential antimicrobial activity against bacterial and fungal plant pathogens (Table 1) [104,105]. 
Table 1. Plant extract-mediated green synthesis of AuNPs and AgNPs with antimicrobial activity.

\begin{tabular}{|c|c|c|c|}
\hline Plant Extract & Synthesized NPs & Target Pathogen & Ref \\
\hline Citrus limetta peel & AgNPs & $\begin{array}{c}\text { Micrococcus luteus, Streptococcus mutans, Staphylococcus } \\
\text { epidermidis, S. aureus, E. coli, Candida spp. }\end{array}$ & [106] \\
\hline Luffa acutangula leaf & AgNPs & E. coli, Saccharomyces cerevisiae & [107] \\
\hline Parkia speciosa leaf & AgNPs & E. coli, S. aureus, Pseudomonas aeruginosa, Bacillus subtilis. & [108] \\
\hline A. indica leaf & AgNPs & S. aureus, E. coli. & [109] \\
\hline Gomphrena globosa leaf & AgNPs & $\begin{array}{c}\text { S. aureus, B. subtilis, M. luteus, E. coli, P. aeruginosa, } \\
\text { Klebsiella pneumoniae. }\end{array}$ & [110] \\
\hline Pedalium murex leaf & AgNPs & $\begin{array}{c}\text { E. coli, K. pneumonia, Micrococcus flavus, P. aeruginosa, } \\
\text { B. subtilis, Bacillus pumilus, S. aureus. }\end{array}$ & [111] \\
\hline Musa acuminate peel & AgNPs & B. subtilis, S. aureus, $P$. aeruginosa, E. coli. & [112] \\
\hline Caulerpa racemosa & AuNPs & Aeromonas veronii, Streptococcus agalactiae & [113] \\
\hline Eclipta alba & AuNPs & E. coli, $P$. aeruginosa, B. subtilis, S. aureus. & [114] \\
\hline Nepenthes khasiana leaf & AuNPs & E. coli, Bacillus spp., Aspergillus niger, Candida albicans. & [115] \\
\hline Abelmoschus esculentus pulp & AuNPs & B. subtilis, Bacillus cereus, E. coli, M. luteus, P. aeruginosa. & [116] \\
\hline
\end{tabular}

A. indica: Azadirachta indica; M. luteus: Micrococcus luteus; S. aureus: Staphylococcus aureus; E. coli: Escherichia coli;

P. aeruginosa: Pseudomonas aeruginosa; B. subtilis: Bacillus subtilis; K. pneumonia: Klebsiella pneumonia.

However, under conventional synthesis methods, these NPs exhibit nearly no antimicrobial activity [117]. The difference may lie in a synergistic effect due to the combination of AuNPs or AgNPs and the plant extracts, which provide high concentrations of steroids, sapogenins, carbohydrates, and flavonoids that act as reducing agents of ions and cover agents, contributing to NPs high stability [118]. Antimicrobial application is primarily due to their ultra-small size and shape (250 times smaller than bacteria), enabling an electrostatic interaction between the Au or Ag from the NPs, and the negative charge on the cell wall or surface of microorganisms, resulting in a distortion of membrane's power functions, such as permeability, osmoregulation, electron transport, and respiration, leading them towards cellular death. The previous depends also on surface availability; thus, smaller NPs will present greater bactericidal effect by binding with the large surface area of the bacteria's cell membrane [119-121].

Nevertheless, the exact antimicrobial mechanism for AuNPs and AgNPs is still poorly understood, for which several theories have been proposed. In the first place, NPs have a strong preference for reacting with sulfhydryl and phosphorus groups on the cell wall, causing great damage that results in the release of bacterial cell components [122]. Another hypothesis states that NPs can penetrate the bacterial cell membrane and attach to NADH dehydrogenases, generating a high amount of reactive oxygen species (ROS), which cause the depletion of ATP and interrupts the respiratory chain. These radicals have the capacity to interact with proteins, sulfur, phosphorus-containing cell constituents, and DNA, destroying them (Figure 3) $[122,123]$. Finally, NPs' release of Au or Ag ions may contribute to their antimicrobial activity since DNA loses its replication activity, and proteins get inactive after interacting with these ions. This biocidal effect is considered to be size and dose-dependent; a higher concentration of NPs have demonstrated to interact more with cytoplasmatic organelles and bacterial nucleic acids [124,125].

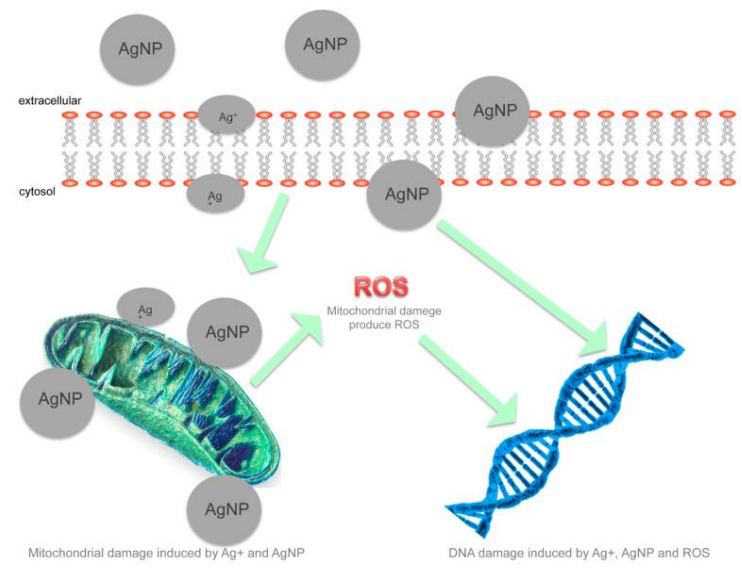

Figure 3. AgNPs antimicrobial mechanism through bacterial cell membrane penetration, interruption of the respiratory chain, and DNA damage by reactive oxygen species (ROS) [126]. 
Moreover, the antimicrobial activity shows differences related to bacterial cell wall composition. AuNPs and AgNPs exhibit higher activity against Gram-negative bacteria than to Gram-positive. The latter possesses a thick layer of peptidoglycan, consisting of linear polysaccharide chains cross-linked by short peptides, which creates a hard rigid structure for NPs to penetrate, while Gram-negative has a thinner that represents a feasible composition to pierce [127,128]. Nevertheless, works from Grace et al. and Padalia et al. reported that NPs' antimicrobial activity could be enhanced by surface modification through coating with aminoglycoside antibiotics, increasing their activity range to Gram-positive bacteria as well $[129,130]$. Wang et al. discovered that gentamicin enhanced bactericidal toxicity of AgNPs against foodborne bacteria S. Aureus, E. coli, and gentamicin-resistant E. coli because the drug promotes NPs dissolution, increasing Ag ions concentration, and promoting bacterial growth inhibition and death [131]. It is worth to mention that this can be a possibility for agricultural labors that employ antibiotics. Although different research groups are raising awareness of the problem and encouraging to dismiss the use of antibiotics in any other field different than medical, under a controlled environment, and highly regulated application, this method can be highly effective and reduce drug resistance issues caused by this human practice [132].

Many research papers in which AuNPs have shown promising antimicrobial activities have highlighted a majority spherical shape character of the NPs. Nevertheless, rod-shaped, triangular, hexagonal, and cubic NPs have also been found as part of the obtained mixture [133]. Thangamani et al. synthesized AuNPs using Simarouba glauca leaf extract. NPs' size and shape were sensitive to leaf broth concentration; particles tended to decrease in size with an increase in leaf broth concentration, while different morphologies were obtained, such as a mixture of the prism and spherical-like particles. Aside from that, they assessed the antimicrobial activity by testing them against Gram-positive and Gram-negative organisms. The antimicrobial assay showed better results for S. aureus, S. mutans, B. subtilis, E. coli, Proteus vulgaris, and K.a pneumonia [134].

Euphorbia hirta aqueous leaf extract was used for biosynthesizing AuNPs by Annamalai et al. NPs sizes ranged from 6-71 nm, which greatly contributed to their highly effective antimicrobial activity against bacterial strains of E. coli, P. aeruginosa, and K. pneumonia. The study evaluated concentrations of $1.25-200 \mathrm{ug} / \mathrm{mL}$, where $200 \mu \mathrm{g} / \mathrm{mL}$ completely inhibited the bacterial growth [135]. Additionally, Folorunso et al. investigated the antimicrobial potency of synthesized AuNPs from the leaf extracts of Annona muricata. The resulted NPs showed a spherical structure with an average size of $25.5 \mathrm{~nm}$ and high antibacterial activity against Clostridium sporogenes, where the efficacy increased as the NPs' concentration increased [136].

In another approach, Montes de Oca et al. evaluated the impact of AgNPs' usual concentrations in nature soils grown with Arabian Coffee in customary and organic operating systems. In this study, biomass, extracellular enzyme activities, and the diversity of the soil microbial community were assessed by a microcosm experiment as a function of time. After 7 days of incubation, the increase in the microbial biomass was independent of NPs concentration [137]. In contrast, after 60 days, there was a decrease in Gram-positive and actinobacterial biomass in soils at all the evaluated AgNPs concentrations. The physicochemical properties of the soil and the enzymatic activities were not affected by AgNPs. Within the composition of the microbial community, only a few differences were observed in abundance relative to the phylum level and gender in the fungal community [137]. The results indicated that the environmental factors of AgNPs affected microbial biomass but had a low impact on microbial diversity and might have a poor effect on soil biogeochemical cycles by extracellular enzyme activities [137,138].

A study by Lediga et al. functionalized AgNPs with the extracts of Sclerocarya birrea and Eucomis autumnalis. Remarkable antimicrobial properties against two Gram-negative and two Gram-positive bacteria were observed. Both the S. birrea and E. autumnalis AgNPs exhibited negligible or low toxicity to plants [139]. Additionally, Shahryari et al. formed AgNPs with an average size of $35 \mathrm{~nm}$ using the sumac aqueous extract through a green synthesis method for controlling bacterial canker disease of stone fruit trees caused by Pseudomonas syringae. The results revealed that different NPs concentrations reduced the severity of the disease, reaching the highest decrease at $100 \mathrm{ppm}$ NPs concentration [140]. 
Moreover, the antimicrobial activity can be used to fight and control fungal pathogens. Jebril et al. green synthesized AgNPs using the leaf extract of Melia azedarach to evaluate its antifungal activity. The researchers reported high efficiency against Verticillium dahliae in eggplant at a concentration of $20 \mathrm{ppm}$ [141]. Besides, Balasubramanian et al. produced AuNPs from the leaf extract of Jasminum auriculatum, which displayed antifungal activity against Aspergillus fumigatus, a very common pathogen in cultivated fields [142].

Furthermore, nanocoatings containing AuNPs and AgNPs have been applied to food contact surfaces and for packaging, taking advantage of their antimicrobial properties. This technology slows down chemical oxidation and degradation processes induced by microorganisms, extending the shelf life of packed crops and other food products $[143,144]$.

\subsection{Water Treatment}

Water quality is fundamental for developing agricultural labors, but also wastewater treatment is worth bringing into the discussion since agricultural labors use about $70 \%$ of the renewable water sources worldwide [145]. Heavy metals, fertilizers, and pesticides employed for agricultural activity have reduced the supply of pure water for drinking and crop irrigation [146]. Nanotechnology can take an important part of a sustainable productivity system, ensuring its quality and purity. The most attractive and cost-effective nanomaterials for environmental protection and water remediation processes are derived from noble metals. In this application, the high surface area to volume ratio, chemical stability, and enhanced catalytic activity properties from plant extract-mediated green synthesized AuNPs and AgNPs can be employed for water monitoring, purification, drinking water treatment, and agriculture wastewater treatment $[147,148]$.

Moreover, research groups have taken advantage of the different properties exhibited by these NPs, including their high reactivity for identifying toxic substances, such as pesticides and heavy metals (e.g., lead, mercury and cadmium), by incorporating them into sensors for the rapid detection of these chemicals $[149,150]$. Water and wastewater detoxification can be achieved by adsorption, photocatalytic degradation, and nanofiltration techniques using NPs as well [151]. Different authors have described the process of pesticide mineralization in water using AuNPs and AgNPs, such as chlorpyrifos, malathion, and atrazine [152]. Pesticides extraction is achieved by their adsorption onto NPs, which retain them on their surface, interacting for long periods until the complex precipitates. Therefore, these NPs represent a suitable, convenient, and cost-effect means of removing pesticides for either drinking water or irrigation labors [152,153]. Moreover, AuNPs and AgNPs are considered an interesting approach for heavy metals elimination in water due to their high adsorption capacity [154].

In addition to that, water pollution with bacterial pathogens represents a high risk for water-borne, food-borne, and plant diseases. The antimicrobial properties of metal NPs have been reported to be effective in this type of water purification [155]. Francis et al. synthesized AuNPs and AgNPs from the leaf extract of Mussaenda glabrata and evaluated their capacity to inhibit pathogenic microorganisms. The NPs showed outstanding antimicrobial activity against P. aeruginosa, E. coli, A. niger, and Penicillium chrysogenum [156]. Besides, their catalytic capacities make them suitable for dye degradation, such as reported by Veisi et al. in their research, where green synthesized AgNPs from the leaf extract of Thymbra spicata decreased different dyes, such as nitrophenol, rhodamin, and methylene blue [157].

\subsection{Development and Delivery of Nanofertilizers, Nanopesticides, and Nanoherbicides}

Agricultural labors are unimaginable without the use of fertilizers for crop nutrition, as well as pesticides and herbicides for protecting crops and plants from several insect pests and plant diseases that continuously hamper the activity, causing high economic loss and food security issues. However, the use of these types of substances has resulted in huge ecotoxicological effects, microbial resistance to agrochemicals, and even accumulation in the human organism [158]. In this sense, nanotechnology can provide specific applications for sustainable development through nanofertilizers, nanopesticides, and nanoherbicides by developing smart delivery systems [159]. Scientists have designed nanocapsules using AuNPs and AgNPs to provide better control of nutrients, increasing the efficacy compared to 
conventional formulations for boosting crop production. This implies a potential reduction of about 10-15 times in the applied dose and frequency. Nanocapsules exhibit a high-loading capacity with a gradual release of the substances, representing beneficial aspects for plant growth since the presence of these NPs in soil may affect root nutrient uptake and water transport, as has been addressed in the following sections [160-162].

AuNPs and AgNPs-based nanofertilizers have been developed to synchronize nutrient release with plant uptake. This system reduces nutrient loss, soil and groundwater contamination, and chemical reactions with water, soil, and microorganisms that transform them into unuseful or toxic substances for plants, helping to maintain the soil's fertility [163-165]. Kang et al. applied 5 mg/L AgNPs fertilizer suspension to red ginseng shoot three times per day at 14-day intervals. After harvesting, they reported that the nanofertilizer had enhanced the ginsenoside content [163].

Nanoencapsulated pesticides and herbicides show enhanced properties in terms of solubility, specificity, permeability, and stability because the nanostructure protects the active substance from early degradation and provides pest control for longer periods [166]. Moreover, control of plant disease-causing phytopathogens, such as bacteria and fungi, can also be achieved by spraying a NPs solution directly on grains, seed, or foliage to inhibit the invasion of plant pathogens [167]. AgNPs green synthesis from Fusarium solani was done by El-Aziz et al. to evaluate their impact on grain borne fungi. The outcome of this research was that sprayed NPs solutions of $4 \%$ caused a $0 \%$ frequency of fungal pathogens [168]. Gnanadesigan et al. biosynthesized AgNPs using the leaf extract of Rhizophora mucronata to evaluate its potential larvicidal activity against Aedes aegypti and Culex quinquefasciatus, two vectors that affect workers in agricultural fields, causing dengue and filariasis [169]. The adoption of high-tech agricultural systems can reduce or even eliminate the negative environmental influence of modern agriculture, as well as enhancing the quality and quantity of crop production [170]. Although NPs for these applications provide a lot of benefits, their different properties give them different toxicities, which need further research [171-173].

\section{Interactions of NPs with Plants: Accumulation and Harmful Effects of NPs in Plants and Crops}

AuNPs and AgNPs are used in different commercial products for agricultural labor, such as nanofertilizers, nanopesticides, and nanoherbicides. The nanosize to which many useful properties are attributable constitutes the factor that can enhance their adverse effects too [174]. Recently, questioning is being raised about their toxicity regarding short- and long-term environmental exposure. Special attention should be paid to the interaction between NPs and plants (e.g., crops) when these materials are used within the agricultural field [175].

Ecotoxicological research is required to demonstrate the environmental consequences of plants constantly exposed to these nanomaterials. NPs in contact with plants can enter to the cellular system, translocate their shoots, and accumulate in different parts. In addition to that, there is a potential risk of cycling through different trophic levels [176]. AuNPs and AgNPs accumulation in plants have shown various effects on the transpiration and respiration rate, which alters the photosynthesis process. At the cellular level, these NPs can alter plants' growth rate and chlorophyll levels, while on the sub-cellular level, investigations have reported organelles modifications and NPs deposition close to the plasmatic membrane [177]. Moreover, the uptake, translocation, and accumulation depend on NPs' size, type, chemical composition, and stability, as well as the plant species [178].

Judy et al. used the model organisms Nicotiana tabacum, Xanthi, and Manduca sexta to evaluate plant uptake and possible trophic transfer upon the exposure to AuNPs of 5, 10, and $15 \mathrm{~nm}$. Their results confirmed trophic transfer and biomagnification of the NPs from a primary producer to a primary consumer by different mean factors related to the NPs' size treatments [179]. Hashimoto et al. found that accumulated AgNPs could translocate to roots and shoots of two terrestrial agro-cropsVigna unguiculata and Triticum aestivum. Recently, it has been demonstrated that AgNPs under aerobic soil conditions are able to maintain their intact nature (88\%), while a transformation to $\mathrm{Ag}_{2} \mathrm{~S}$ can also occur in the same extension [180]. 
While it is not clear how metal NPs affect the environment, some studies reveal that plants overexposed to them may reveal pathways involved in the cytotoxicity. Proteomic studies on Oryza sativa (Asian rice) with AuNPs and AgNPs have increased protein precursors for oxidative stress tolerance, calcium regulation and signaling, apoptosis, and other kinds of damages [181]. Additionally, Vanini et al. developed research to study the proteomic profile of Eruca sativa exposed to AgNPs and bulk Ag. Seedlings were treated for five days with different concentrations of $\mathrm{AgNPs}$ and $\mathrm{AgNO}_{3}$, resulting in changes in proteins involved in redox regulation and the sulfur metabolism for both cases. However, further analysis revealed an altered number of proteins in the endoplasmic reticulum and vacuole of plant cells caused by AgNPs [182]. Kaveh et al. studied the model agro-crop Arabidopsis thaliana and reported the phytoaccumulation of AgNPs [183]. Another approach developed by Taylor et al. described Medicago Sativa L. (alfalfa) tendency to accumulate metal NPs of different sizes [184].

A research conducted by Raliya et al. studied uptake, translocation, and accumulation of different AgNPs with sizes ranging from 30-80 nm delivered by aerosol application to a watermelon plant. The findings indicate that NPs could be taken up by direct penetration and transport through the stomatal opening. Besides, they observed translocation of NPs from leaf to shoots, which suggests they travel by the phloem transport mechanism (i.e., the mechanism of long-distance transport through plant's sieve tube) [185]. It has been reported that Au is taken up in A. thaliana predominantly in an ionic form, having a significant role in seed germination and antioxidant system. However, other studies suggest that AuNPs' exposure results in the upregulation of plant genes, causing downregulation of specific-metal transporters to reduce Au uptake [184]. This can be used for studying the limits of NPs in the environment.

Moreover, Qian et al. discovered that high concentrations of Ag could be overwhelming to A. thaliana seeds, which should not be exposed to AgNPs during its germination [186]. In contrast, Stampoulis et al. reported no toxic effect on seed germination and root elongation of Cucurbita pepo (zucchini) when exposing to AuNPs and AgNPs. However, in a 15-day hydroponic trial, the biomass and transpiration of the plants exposed to AgNPs were reduced by 75\% and 41\%, respectively, as compared to control plants and the corresponding bulk Ag powder. Additionally, zucchini shoots exposed to these NPs contained, on average, 4.7 greater Ag concentration than the ones from bulk solutions [187]. Germination studies in Lolium perenne, Hordeum vulgare, and Linum usitatissimum have shown to be affected at low concentrations of AgNPs but never fully inhibited [188]. This suggests that different mechanisms of action might occur across plant species, concerning the effect on germination [189].

Courtois et al. published an important study of the impact of Ag species introduced into the soil via sewage sludge. As mentioned before, AgNPs are incorporated into many conventional and novel products due to their special physicochemical and antimicrobial properties. However, the discharge of these products into wastewater causes an accumulation of $\mathrm{AgNPs}$ and $\mathrm{Ag}_{2} \mathrm{~S}$ in sewage sludge. The major concern is related to land application of sewage sludge for agricultural purposes since soils receive a great source of contamination for plants and crops. Soil exposure to metal NPs may lead to changes in microbial biomass that can affect plant growth, causing physiological, biochemical, and molecular effects on them. Nonetheless, much is still unknown about the ecotoxicology of silver species, where several doubts are focused on the possibility of transfer along the trophic chain via accumulation in plants, and for that, research to evaluate the long-term impact of AgNPs on plants is ongoing [190].

\section{AuNPs and AgNPs in Soils}

Biological indicators are important parameters for evaluating soil quality since soil microbiota directly participates in different processes of this ecosystem, such as decomposition of inorganic matter and nutrient cycling. Therefore, any factor that alters soil microbial biomass will have an impact on soil sustainability [191]. Needless to say, the growing use of AuNPs and AgNPs due to their recognized antimicrobial activity has led to their accumulation in soil ecosystems, affecting its quality [192,193]. Although their environmental impact on the soil microbial community is still under consideration, 
several authors have concluded that the toxic effects on microbial communities are highly dependent on their concentration in the soil [194-198]. However, most studies have evaluated NPs at higher levels than actually occur in nature [199-201].

Dinesh et al. stated that NPs might have an impact on the soil in different ways. Firstly, a direct effect could be attributed to their properties, such as their antimicrobial activity, which might reduce soil microbiota mostly by generating ROS. In the second place, NPs could induce changes in toxins and nutrients bioavailability. Finally, the indirect effects might result from their interaction with natural organic toxic compounds, thus enhancing their toxicity [191]. In addition to that, different studies have proven that AgNPs affect microorganisms that promote plant growth and nutrient cycling in soils, such as rhizobacteria, Pseudomonas fluorescens, Pseudomonas putida, and others. A major concern is related to the inhibition of denitrifying bacteria, where studies have reported that at concentrations of $100 \mathrm{mg}$ of AgNPs/kg of soil, can be observed a complete reduction of these colonies without recovery signals and with the consequence of the reduced conversion of nitrates to nitrogen [191,202].

NPs can affect other soil organisms, such as earthworms. Unrine et al. determined AuNPs bioavailability from soil to Eisenia fetida. They reported that NPs sizes ranging from 20-55 nm did not influence distribution among tissues in contrast to the ones smaller than $20 \mathrm{~nm}$, which were more available. In addition to that, AuNPs could cause adverse effects on earthworm reproduction [203]. Bourdineaud et al. also used E. fetida to evaluate the transfer of AuNPs and AgNPs from soil to the earthworm tissues. In this study, the invertebrate was exposed to soil containing 2, 10, and $50 \mathrm{mg}$ of NPs/kg of soil for 10 days. Both NPs showed similar transfer coefficients and induced the onset of oxidative stress that caused DNA modifications even at the lowest evaluated concentration [204]. Another study by Schlich et al. evaluated the effects of AgNPs on Eisenia Andrei earthworm reproduction. Ag uptake from the NPs was slightly higher compared to $\mathrm{AgNO}_{3}$, where both substances showed similar toxicities in the reproduction test. However, Ag uptake was not reported to inhibit reproduction [205]. In contrast, Ploeg et al. described the reduction in the reproduction of Lumbricus rubellus earthworms influenced by AgNPs, which also caused mortality upon long-term exposure [206].

In addition to NPs concentration in soil, ecotoxicological studies should take into consideration dissolution rate, size, surface area, electric charge, and their surface chemistry since these control NPs' stability and their transport, giving relevant and more accurate outcomes about their toxicity. Furthermore, dispersibility is also considered as a key factor; agglomerates of NPs have shown less toxicity compared to well-dispersed forms. A way of promoting that is by using biodegradable polymers as stabilizing agents obtained through green methods, such as chitosan, wood cellulose, gelatin, among others [207]. Moreover, the behavior of NPs within soil systems is influenced by the presence of surface charged components, such as clay, which alters their association with the solid phase. This interaction between NPs and solid surfaces controls their transport along with the soil, which is influenced by environmental conditions and the NPs' physicochemical properties. Particle retention in pore soils is especially relevant to the bigger NPs, whereas smaller particles tend to move more freely and can penetrate to reach groundwater [208].

Meier et al. presented the concern that anthropogenic activities could disrupt soil ecosystems, resulting in the reduction of its microbial health. In order to evaluate the previous, they exposed freshly collected sandy loam soil to solutions ranging from 0-2000 mg/kg of AgNPs. After that, they expanded traditional soil microbial analysis with genomics-based tests through the measure of alterations in community taxonomic structure and function using 16S-rDNA profiling and metatranscriptomics. The research group found that AgNPs affected bacterial taxonomic structure, as well as genes involved in heavy metal resistance. Besides, their presence induced some toxicity response pathways to become highly upregulated [209].

In Canada, AgNPs are employed for direct application in soils to reduce the utilization and degradation of conventional pesticides, provide micronutrients, increase crop yields, and control plant pathogens. Regarding that, Asadishad et al. evaluated the effects of AgNPs on the soil microbiota and enzyme activity of agricultural soils at different concentrations (1, 10, or $100 \mathrm{mg}$ of $\mathrm{AgNPs} / \mathrm{kg}$ of soil) 
over 30 days. At the end of that period, AgNPs inhibited selected enzymes at the concentration of $100 \mathrm{mg} / \mathrm{kg}$, causing interesting changes in soil microbial community [210]. Another study by Li et al. described the impact of $\mathrm{AgNPs}$ on the soil. $\mathrm{Ag}_{2} \mathrm{~S}$ is more likely to be the form in which silver is retained in soils. They examined $\mathrm{Ag}_{2} \mathrm{~S}$ retention from 11 natural different soils and discovered that more than $99 \%$ of the NPs were retained irrespective of the soil properties. Since the retention of $\mathrm{Ag}_{2} \mathrm{~S}$ in soils is conceived as a critical factor for their toxicity and availability to sustain life (e.g., plants), the results obtained by this group can be a good approach for explaining the differences in phytoavailability exhibited by soils compared to what is established in the literature for liquid media [211].

\section{Conclusions}

Green chemistry is an innovative and growing resource in the search for more environmentally friendly processes. Using plant extracts for the synthesis of metal NPs is a recently growing area of interest due to its benefit in comparison to the traditional physicochemical methods. AuNPs and AgNPs generated by green synthesis have potential applications in agriculture and agroindustry, especially as antimicrobial agents of certain microorganisms for which their efficacy has been scientifically proven. Although recent studies suggest that environmental concentrations of AuNPs and AgNPs affect microbial biomass with low impact on their diversity, further research needs to be addressed in order to determine the effects they could produce to the soil, plants, and the environment, in general, due to long-term exposure. Therefore, local and national regulatory institutions must establish guidelines and monitoring methods for better use of these nanotechnological advances.

Author Contributions: Conceptualization, J.R.V.-B. and G.M.d.O.-V.; methodology, L.C.-H., J.R.V.-B., J.U.-Á. and K.A.-A.; investigation, L.C.-H., J.U.-Á., K.A.-A. and L.V.-F.; resources, J.R.V.-B.; writing-original draft preparation, L.C.-H., G.M.d.O.-V., L.V.-F. and K.A.-A.; writing—review and editing, L.C.-H. and J.R.V.-B.; visualization, J.U.-Á., G.M.d.O.-V. and L.V.-F; supervision, J.R.V.-B. and G.M.d.O.-V.; project administration, J.R.V.-B. All authors have read and agreed to the published version of the manuscript.

Funding: This research received no external funding.

Conflicts of Interest: The authors declare no conflict of interest.

\section{References}

1. De Marco, B.A.; Rechelo, B.S.; Tótoli, E.G.; Kogawa, A.C.; Salgado, H.R.N. Evolution of green chemistry and its multidimensional impacts: A review. Saudi Pharm. J. 2019, 27, 1-8. [CrossRef] [PubMed]

2. Hurst, G.A. Systems thinking approaches for international green chemistry education. Curr. Opin. Green Sustain. Chem. 2020, 21, 93-97. [CrossRef]

3. Falcone, P.M.; Hiete, M. Exploring green and sustainable chemistry in the context of sustainability transition: The role of visions and policy. Curr. Opin. Green Sustain. Chem. 2019, 19, 66-75. [CrossRef]

4. Menges, N. The Role of Green Solvents and Catalysts at the Future of Drug Design and of Synthesis. Green Chem. 2017. [CrossRef]

5. Chen, T.-L.; Kim, H.; Pan, S.-Y.; Tseng, P.-C.; Lin, Y.-P.; Chiang, P.-C. Implementation of green chemistry principles in circular economy system towards sustainable development goals: Challenges and perspectives. Sci. Total Environ. 2020, 716, 136998. [CrossRef]

6. Ramón, A.J.L.; González, J.L.V. Especies Vegetales Valeriana pilosa, Hesperomeles ferruginea, Myrcianthes rhopaloides y Passiflora manicata Frente a Microrganismos Patogenos y Fitopatogenos. Ph.D. Thesis, Facultad de Ciencias, Pontificia Universidad Javeriana, Bogotá, Colombia, 2008.

7. Loste, N.; Chinarro, D.; Gomez, M.; Roldán, E.; Giner, B. Assessing awareness of green chemistry as a tool for advancing sustainability. J. Clean. Prod. 2020, 256, 120392. [CrossRef]

8. Zuin, V.G.; Stahl, A.M.; Zanotti, K.; Segatto, M.L. Green and Sustainable Chemistry in Latin America: Which type of research is going on? And for what? Curr. Opin. Green Sustain. Chem. 2020, 100379. [CrossRef]

9. Vega-Baudrit, J.; Gamboa, S.M.; Rojas, E.R.; Martinez, V.V. Synthesis and characterization of silver nanoparticles and their application as an antibacterial agent. Int. J. Biosens. Bioelectron 2019, 5. [CrossRef] 
10. Vaid, P.; Raizada, P.; Saini, A.K.; Saini, R.V. Biogenic silver, gold and copper nanoparticles-A sustainable green chemistry approach for cancer therapy. Sustain. Chem. Pharm. 2020, 16, 100247. [CrossRef]

11. Mondal, P.; Anweshan, A.; Purkait, M.K. Green synthesis and environmental application of iron-based nanomaterials and nanocomposite: A review. Chemosphere 2020, 259, 127509. [CrossRef]

12. Khan, I.; Saeed, K.; Khan, I. Nanoparticles: Properties, applications and toxicities. Arab. J. Chem. 2019, 12, 908-931. [CrossRef]

13. Saleh, T.A.; Gupta, V.K. Chapter 4-Synthesis, Classification, and Properties of Nanomaterials. In Nanomaterial and Polymer Membranes; Saleh, T.A., Gupta, V.K., Eds.; Elsevier: Amsterdam, The Netherlands, 2016; pp. 83-133. ISBN 978-0-12-804703-3.

14. Guleria, A.; Neogy, S.; Raorane, B.S.; Adhikari, S. Room temperature ionic liquid assisted rapid synthesis of amorphous Se nanoparticles: Their prolonged stabilization and antioxidant studies. Mater. Chem. Phys. 2020, 253, 123369. [CrossRef]

15. Sudha, P.N.; Sangeetha, K.; Vijayalakshmi, K.; Barhoum, A. Chapter 12-Nanomaterials history, classification, unique properties, production and market. In Emerging Applications of Nanoparticles and Architecture Nanostructures; Barhoum, A., Makhlouf, A.S.H., Eds.; Micro and Nano Technologies; Elsevier: Amsterdam, The Netherlands, 2018; pp. 341-384. ISBN 978-0-323-51254-1.

16. Dolez, P.I. Chapter 1.1-Nanomaterials Definitions, Classifications, and Applications. In Nanoengineering; Dolez, P.I., Ed.; Elsevier: Amsterdam, The Netherlands, 2015; pp. 3-40. ISBN 978-0-444-62747-6.

17. Menazea, A.A.; Ahmed, M.K. Synthesis and antibacterial activity of graphene oxide decorated by silver and copper oxide nanoparticles. J. Mol. Struct. 2020, 1218, 128536. [CrossRef]

18. Panicker, S.; Ahmady, I.M.; Han, C.; Chehimi, M.; Mohamed, A.A. On demand release of ionic silver from gold-silver alloy nanoparticles: Fundamental antibacterial mechanisms study. Mater. Today Chem. 2020, 16, 100237. [CrossRef]

19. Acharya, A.; Pal, P.K. Agriculture nanotechnology: Translating research outcome to field applications by influencing environmental sustainability. NanoImpact 2020, 19, 100232. [CrossRef]

20. Chandra, H.; Kumari, P.; Bontempi, E.; Yadav, S. Medicinal plants: Treasure trove for green synthesis of metallic nanoparticles and their biomedical applications. Biocatal. Agric. Biotechnol. 2020, 24, 101518. [CrossRef]

21. Ahmed, S.; Annu; Ikram, S.; Yudha, S.S. Biosynthesis of gold nanoparticles: A green approach. J. Photochem. Photobiol. B 2016, 161, 141-153. [CrossRef]

22. Mahawar, H.; Prasanna, R. Prospecting the interactions of nanoparticles with beneficial microorganisms for developing green technologies for agriculture. Environ. Nanotechnol. Monit. Manag. 2018, 10, 477-485. [CrossRef]

23. Raveendran, P.; Fu, J.; Wallen, S.L. Completely “Green” Synthesis and Stabilization of Metal Nanoparticles. J. Am. Chem. Soc. 2003, 125, 13940-13941. [CrossRef]

24. Iravani, S. Green synthesis of metal nanoparticles using plants. Green Chem. 2011, 13, 2638-2650. [CrossRef]

25. Mittal, A.K.; Chisti, Y.; Banerjee, U.C. Synthesis of metallic nanoparticles using plant extracts. Biotechnol. Adv. 2013, 31, 346-356. [CrossRef] [PubMed]

26. Logeswari, P.; Silambarasan, S.; Abraham, J. Ecofriendly synthesis of silver nanoparticles from commercially available plant powders and their antibacterial properties. Sci. Iran. 2013, 20, 1049-1054. [CrossRef]

27. Yang, N.; WeiHong, L.; Hao, L. Biosynthesis of Au nanoparticles using agricultural waste mango peel extract and its in vitro cytotoxic effect on two normal cells. Mater. Lett. 2014, 134, 67-70. [CrossRef]

28. Verma, A.; Mehata, M.S. Controllable synthesis of silver nanoparticles using Neem leaves and their antimicrobial activity. J. Radiat. Res. Appl. Sci. 2016, 9, 109-115. [CrossRef]

29. Bagherzade, G.; Tavakoli, M.M.; Namaei, M.H. Green synthesis of silver nanoparticles using aqueous extract of saffron (Crocus sativus L.) wastages and its antibacterial activity against six bacteria. Asian Pac. J. Trop. Biomed. 2017, 7, 227-233. [CrossRef]

30. Sherin, L.; Sohail, A.; Amjad, U.-S.; Mustafa, M.; Jabeen, R.; Ul-Hamid, A. Facile green synthesis of silver nanoparticles using Terminalia bellerica kernel extract for catalytic reduction of anthropogenic water pollutants. Colloid Interface Sci. Commun. 2020, 37, 100276. [CrossRef]

31. Li, M.; Yu, H.; Cheng, Y.; Guo, Y.; Yao, W.; Xie, Y. Simultaneous and rapid determination of polycyclic aromatic hydrocarbons by facile and green synthesis of silver nanoparticles as effective SERS substrate. Ecotoxicol. Environ. Saf. 2020, 200, 110780. [CrossRef] 
32. Trotsiuk, L.; Antanovich, A.; Lizunova, A.; Kulakovich, O. Direct synthesis of amphiphilic polyvinylpyrrolidonecapped gold nanoparticles in chloroform. Colloid Interface Sci. Commun. 2020, 37, 100289. [CrossRef]

33. Adamo, C.B.; Junger, A.S.; Bressan, L.P.; da Silva, J.A.F.; Poppi, R.J.; de Jesus, D.P. Fast and straightforward in-situ synthesis of gold nanoparticles on a thread-based microfluidic device for application in surface-enhanced Raman scattering detection. Microchem. J. 2020, 156, 104985. [CrossRef]

34. Bandeira, M.; Giovanela, M.; Roesch-Ely, M.; Devine, D.M.; da Silva Crespo, J. Green synthesis of zinc oxide nanoparticles: A review of the synthesis methodology and mechanism of formation. Sustain. Chem. Pharm. 2020, 15, 100223. [CrossRef]

35. Ohara, Y.; Akazawa, K.; Shibata, K.; Hirota, T.; Kodama, Y.; Amemiya, T.; Wang, J.; Yamaguchi, T. Seed-mediated gold nanoparticle synthesis via photochemical reaction of benzoquinone. Colloids Surf. Physicochem. Eng. Asp. 2020, 586, 124209. [CrossRef]

36. Pandey, A.; Tripathi, S. Concept of standardization, extraction and pre phytochemical screening strategies for herbal drug. J. Pharmacogn. Phytochem. 2014, 2, 115-119.

37. Belokurov, S.S.; Narkevich, I.A.; Flisyuk, E.V.; Kaukhova, I.E.; Aroyan, M.V. Modern Extraction Methods for Medicinal Plant Raw Material (Review). Pharm. Chem. J. 2019, 53, 559-563. [CrossRef]

38. Azwanida, N.N. A Review on the Extraction Methods Use in Medicinal Plants, Principle, Strength and Limitation. Med. Aromat. Plants 2015, 4. [CrossRef]

39. Yahya, N.A.; Attan, N.; Wahab, R.A. An overview of cosmeceutically relevant plant extracts and strategies for extraction of plant-based bioactive compounds. Food Bioprod. Process. 2018, 112, 69-85. [CrossRef]

40. Dekebo, A. Introductory Chapter. Plant Extr. 2019. [CrossRef]

41. Zhang, Q.-W.; Lin, L.-G.; Ye, W.-C. Techniques for extraction and isolation of natural products: A comprehensive review. Chin. Med. 2018, 13. [CrossRef]

42. Schlosser, Š.; Kertész, R.; Marták, J. Recovery and separation of organic acids by membrane-based solvent extraction and pertraction: An overview with a case study on recovery of MPCA. Sep. Purif. Technol. 2005, 41, 237-266. [CrossRef]

43. Hashemi, B.; Zohrabi, P.; Dehdashtian, S. Application of green solvents as sorbent modifiers in sorptive-based extraction techniques for extraction of environmental pollutants. TrAC Trends Anal. Chem. 2018, 109, 50-61. [CrossRef]

44. Sánchez-Camargo, A.d.P.; Bueno, M.; Parada-Alfonso, F.; Cifuentes, A.; Ibáñez, E. Hansen solubility parameters for selection of green extraction solvents. TrAC Trends Anal. Chem. 2019, 118, 227-237. [CrossRef]

45. Bhat, A.R.; Najar, M.H.; Dongre, R.S.; Akhter, M.S. Microwave assisted synthesis of Knoevenagel Derivatives using water as green solvent. Curr. Res. Green Sustain. Chem. 2020. [CrossRef]

46. Lux, C.; Lubio, A.; Ruediger, A.; Robert, S.; Muehlethaler, C. Optimizing the analysis of dyes by SurfaceEnhanced Raman Spectroscopy (SERS) using a conventional-microwave silver nanoparticles synthesis. Forensic Chem. 2019, 16, 100186. [CrossRef]

47. Ahmed, S.; Ahmad, M.; Swami, B.L.; Ikram, S. A review on plants extract mediated synthesis of silver nanoparticles for antimicrobial applications: A green expertise. J. Adv. Res. 2016, 7, 17-28. [CrossRef] [PubMed]

48. Rao, S.S.; Saptami, K.; Venkatesan, J.; Rekha, P.D. Microwave-assisted rapid synthesis of silver nanoparticles using fucoidan: Characterization with assessment of biocompatibility and antimicrobial activity. Int. J. Biol. Macromol. 2020. [CrossRef]

49. Trusheva, B.; Trunkova, D.; Bankova, V. Different extraction methods of biologically active components from propolis: A preliminary study. Chem. Cent. J. 2007, 1, 13. [CrossRef]

50. Oroian, M.; Dranca, F.; Ursachi, F. Comparative evaluation of maceration, microwave and ultrasonic-assisted extraction of phenolic compounds from propolis. J. Food Sci. Technol. 2020, 57, 70-78. [CrossRef]

51. Ferioli, F.; Giambanelli, E.; D'Alessandro, V.; D'Antuono, L.F. Comparison of two extraction methods (high pressure extraction vs. maceration) for the total and relative amount of hydrophilic and lipophilic organosulfur compounds in garlic cloves and stems. An application to the Italian ecotype "Aglio Rosso di Sulmona" (Sulmona Red Garlic). Food Chem. 2020, 312, 126086. [CrossRef]

52. Altemimi, A.; Lakhssassi, N.; Baharlouei, A.; Watson, D.G.; Lightfoot, D.A. Phytochemicals: Extraction, Isolation, and Identification of Bioactive Compounds from Plant Extracts. Plants 2017, 6, 42. [CrossRef]

53. Chemat, F.; Rombaut, N.; Sicaire, A.-G.; Meullemiestre, A.; Fabiano-Tixier, A.-S.; Abert-Vian, M. Ultrasound assisted extraction of food and natural products. Mechanisms, techniques, combinations, protocols and applications. A review. Ultrason. Sonochem. 2017, 34, 540-560. [CrossRef] 
54. Varma, R.S. Greener approach to nanomaterials and their sustainable applications. Curr. Opin. Chem. Eng. 2012, 1, 123-128. [CrossRef]

55. Nogueira, L.F.B.; Guidelli, É.J.; Jafari, S.M.; Ramos, A.P. 7-Green synthesis of metal nanoparticles by plant extracts and biopolymers. In Handbook of Food Nanotechnology; Jafari, S.M., Ed.; Academic Press: Cambridge, MA, USA, 2020; pp. 257-278. ISBN 978-0-12-815866-1.

56. Hekmati, M.; Hasanirad, S.; Khaledi, A.; Esmaeili, D. Green synthesis of silver nanoparticles using extracts of Allium rotundum 1, Falcaria vulgaris Bernh, and Ferulago angulate Boiss, and their antimicrobial effects in vitro. Gene Rep. 2020, 19, 100589. [CrossRef]

57. Khalaj, M.; Kamali, M.; Costa, M.E.V.; Capela, I. Green synthesis of nanomaterials-A scientometric assessment. J. Clean. Prod. 2020, 267, 122036. [CrossRef]

58. Yadi, M.; Mostafavi, E.; Saleh, B.; Davaran, S.; Aliyeva, I.; Khalilov, R.; Nikzamir, M.; Nikzamir, N.; Akbarzadeh, A.; Panahi, Y.; et al. Current developments in green synthesis of metallic nanoparticles using plant extracts: A review. Artif. Cells Nanomedicine Biotechnol. 2018, 46, S336-S343. [CrossRef] [PubMed]

59. Hou, D.; O'Connor, D. Chapter 1 -Green and sustainable remediation: Concepts, principles, and pertaining research. In Sustainable Remediation of Contaminated Soil and Groundwater; Hou, D., Ed.; Butterworth-Heinemann: Waltham, MA, USA, 2020; pp. 1-17. ISBN 978-0-12-817982-6.

60. Fasciotti, M. Perspectives for the use of biotechnology in green chemistry applied to biopolymers, fuels and organic synthesis: From concepts to a critical point of view. Sustain. Chem. Pharm. 2017, 6, 82-89. [CrossRef]

61. Dauthal, P.; Mukhopadhyay, M. Noble Metal Nanoparticles: Plant-Mediated Synthesis, Mechanistic Aspects of Synthesis, and Applications. Ind. Eng. Chem. Res. 2016, 55, 9557-9577. [CrossRef]

62. Sreeprasad, T.S.; Pradeep, T. Noble Metal Nanoparticles. In Springer Handbook of Nanomaterials; Vajtai, R., Ed.; Springer Handbooks; Springer: Berlin/Heidelberg, Germany, 2013; pp. 303-388. ISBN 978-3-642-20595-8.

63. Jamkhande, P.G.; Ghule, N.W.; Bamer, A.H.; Kalaskar, M.G. Metal nanoparticles synthesis: An overview on methods of preparation, advantages and disadvantages, and applications. J. Drug Deliv. Sci. Technol. 2019, 53, 101174. [CrossRef]

64. Narayanan, K.B.; Sakthivel, N. Green synthesis of biogenic metal nanoparticles by terrestrial and aquatic phototrophic and heterotrophic eukaryotes and biocompatible agents. Adv. Colloid Interface Sci. 2011, 169, 59-79. [CrossRef] [PubMed]

65. Gour, A.; Jain, N.K. Advances in green synthesis of nanoparticles. Artif. Cells Nanomed. Biotechnol. 2019, 47, 844-851. [CrossRef] [PubMed]

66. Golinska, P.; Wypij, M.; Ingle, A.P.; Gupta, I.; Dahm, H.; Rai, M. Biogenic synthesis of metal nanoparticles from actinomycetes: Biomedical applications and cytotoxicity. Appl. Microbiol. Biotechnol. 2014, 98, 8083-8097. [CrossRef]

67. Rafique, M.; Sadaf, I.; Rafique, M.S.; Tahir, M.B. A review on green synthesis of silver nanoparticles and their applications. Artif. Cells Nanomed. Biotechnol. 2017, 45, 1272-1291. [CrossRef]

68. Mazhar, T.; Shrivastava, V.; Tomar, R.S. Green Synthesis of Bimetallic Nanoparticles and its Applications: A Review. J. Pharm. Sci. Res. 2017, 9, 102.

69. Hussain, I.; Singh, N.B.; Singh, A.; Singh, H.; Singh, S.C. Green synthesis of nanoparticles and its potential application. Biotechnol. Lett. 2016, 38, 545-560. [CrossRef]

70. Zhang, T.; Song, Y.-J.; Zhang, X.-Y.; Wu, J.-Y. Synthesis of Silver Nanostructures by Multistep Methods. Sensors 2014, 14, 5860-5889. [CrossRef] [PubMed]

71. Sani, M.; Tatiana, A. Síntesis y caracterización de nanopartículas de plata a partir de varios extractos pigmentados de dos plantas para su aplicación en celdas solares híbridas. Bachelor's Thesis, Facultad de Ingeniería, Universidad de las Fuerzas Armadas, Latacunga, Ecuador, 2017.

72. Bhattarai, B.; Zaker, Y.; Bigioni, T.P. Green synthesis of gold and silver nanoparticles: Challenges and opportunities. Curr. Opin. Green Sustain. Chem. 2018, 12, 91-100. [CrossRef]

73. Arias Ortiz, J.D.; Palma Holguín, M.I. Elaboración de un Compuesto Antimicrobial con Nanopartículas de Plata Sintetizadas a Partir del Extracto de Hojas de Romero (Rosmarinus Officinalis), Para ser Aplicado en Frutas Frescas. Ph.D. Thesis, Facultad de Ingeniería Química, Universidad de Guayaquil: Guayaquil, Ecuador, 2019.

74. Noah, N. Chapter 6-Green synthesis: Characterization and application of silver and gold nanoparticles. In Green Synthesis, Characterization and Applications of Nanoparticles; Shukla, A.K., Iravani, S., Eds.; Micro and Nano Technologies; Elsevier: Amsterdam, The Netherlands, 2019; pp. 111-135. ISBN 978-0-08-102579-6. 
75. Gopinath, V.; MubarakAli, D.; Priyadarshini, S.; Priyadharsshini, N.M.; Thajuddin, N.; Velusamy, P. Biosynthesis of silver nanoparticles from Tribulus terrestris and its antimicrobial activity: A novel biological approach. Colloids Surf. B Biointerfaces 2012, 96, 69-74. [CrossRef]

76. Kumar, D.A.; Palanichamy, V.; Roopan, S.M. Green synthesis of silver nanoparticles using Alternanthera dentata leaf extract at room temperature and their antimicrobial activity. Spectrochim. Acta. A Mol. Biomol. Spectrosc. 2014, 127, 168-171. [CrossRef]

77. Nakkala, J.R.; Mata, R.; Gupta, A.K.; Sadras, S.R. Biological activities of green silver nanoparticles synthesized with Acorous calamus rhizome extract. Eur. J. Med. Chem. 2014, 85, 784-794. [CrossRef]

78. Nakkala, J.R.; Mata, R.; Bhagat, E.; Sadras, S.R. Green synthesis of silver and gold nanoparticles from Gymnema sylvestre leaf extract: Study of antioxidant and anticancer activities. J. Nanopart. Res. 2015, 17, 151. [CrossRef]

79. Muthukumar, H.; Palanirajan, S.K.; Shanmugam, M.K.; Gummadi, S.N. Plant extract mediated synthesis enhanced the functional properties of silver ferrite nanoparticles over chemical mediated synthesis. Biotechnol. Rep. 2020, 26, e00469. [CrossRef]

80. Pereira, T.M.; Polez, V.L.P.; Sousa, M.H.; Silva, L.P. Modulating physical, chemical, and biological properties of silver nanoparticles obtained by green synthesis using different parts of the tree Handroanthus heptaphyllus (Vell.) Mattos. Colloid Interface Sci. Commun. 2020, 34, 100224. [CrossRef]

81. Rajakumar, G.; Abdul Rahuman, A. Larvicidal activity of synthesized silver nanoparticles using Eclipta prostrata leaf extract against filariasis and malaria vectors. Acta Trop. 2011, 118, 196-203. [CrossRef]

82. Arreche, R.A.; Montes de Oca-Vásquez, G.; Vega-Baudrit, J.R.; Vázquez, P.G. Synthesis of Silver Nanoparticles Using Extracts from Yerba Mate (Ilex paraguariensis) Wastes. Waste Biomass Valorization 2020, 11, $245-253$. [CrossRef]

83. Sasidharan, D.; Namitha, T.R.; Johnson, S.P.; Jose, V.; Mathew, P. Synthesis of silver and copper oxide nanoparticles using Myristica fragrans fruit extract: Antimicrobial and catalytic applications. Sustain. Chem. Pharm. 2020, 16, 100255. [CrossRef]

84. Alkhalaf, M.I.; Hussein, R.H.; Hamza, A. Green synthesis of silver nanoparticles by Nigella sativa extract alleviates diabetic neuropathy through anti-inflammatory and antioxidant effects. Saudi. J. Biol. Sci. 2020. [CrossRef]

85. Kesarla, M.K.; Mandal, B.K.; Bandapalli, P.R. Gold nanoparticles by Terminalia bellirica aqueous extract-A rapid green method. J. Exp. Nanosci. 2014, 9, 825-830. [CrossRef]

86. Sk, I.; Khan, M.A.; Haque, A.; Ghosh, S.; Roy, D.; Homechuadhuri, S.; Alam, A. Synthesis of Gold and Silver Nanoparticles Using Malva Verticillata Leaves Extract: Study of Gold Nanoparticles Catalysed Reduction of Nitro-Schiff Bases and Antibacterial Activities of Silver Nanoparticles. Curr. Res. Green Sustain. Chem. 2020. [CrossRef]

87. Synthesis of Silver and Gold Nanoparticles Using Antioxidants from Blackberry, Blueberry, Pomegranate, and Turmeric Extracts | ACS Sustainable Chemistry \& Engineering. Available online: https://pubs.acs.org/ doi/abs/10.1021/sc500237k?casa_token=DctBHkR3nPcAAAAA:ykRDDTZp16tSl5gF5SMbQJAjW6X9qZYP2qJn1zQw5HN8xnKzwwExngH8fVnf_8elH5nOt59Ji7qE5Wh (accessed on 27 July 2020).

88. Zhang, L.; Mazouzi, Y.; Salmain, M.; Liedberg, B.; Boujday, S. Antibody-Gold Nanoparticle Bioconjugates for Biosensors: Synthesis, Characterization and Selected Applications. Biosens. Bioelectron. 2020, 112370. [CrossRef]

89. Cox, A.; Venkatachalam, P.; Sahi, S.; Sharma, N. Reprint of: Silver and titanium dioxide nanoparticle toxicity in plants: A review of current research. Plant Physiol. Biochem. PPB 2017, 110, 33-49. [CrossRef]

90. Dasgupta, N.; Ranjan, S.; Mundekkad, D.; Ramalingam, C.; Shanker, R.; Kumar, A. Nanotechnology in agro-food: From field to plate. Food Res. Int. 2015, 69, 381-400. [CrossRef]

91. Awad, M.A.; Eisa, N.E.; Virk, P.; Hendi, A.A.; Ortashi, K.M.O.O.; Mahgoub, A.S.A.; Elobeid, M.A.; Eissa, F.Z. Green synthesis of gold nanoparticles: Preparation, characterization, cytotoxicity, and anti-bacterial activities. Mater. Lett. 2019, 256, 126608. [CrossRef]

92. Takeuchi, M.T.; Kojima, M.; Luetzow, M. State of the art on the initiatives and activities relevant to risk assessment and risk management of nanotechnologies in the food and agriculture sectors. Food Res. Int. 2014, 64, 976-981. [CrossRef]

93. Marchiol, L.; Mattiello, A.; Pošćić, F.; Giordano, C.; Musetti, R. In vivo synthesis of nanomaterials in plants: Location of silver nanoparticles and plant metabolism. Nanoscale Res. Lett. 2014, 9, 101. [CrossRef] [PubMed] 
94. Ribeiro, C.A.S.; Albuquerque, L.J.C.; de Castro, C.E.; Batista, B.L.; de Souza, A.L.M.; Albuquerque, B.L.; Zilse, M.S.; Bellettini, I.C.; Giacomelli, F.C. One-pot synthesis of sugar-decorated gold nanoparticles with reduced cytotoxicity and enhanced cellular uptake. Colloids Surf. Physicochem. Eng. Asp. 2019, 580, 123690. [CrossRef]

95. Vijayaraghavan, K.; Ashokkumar, T. Plant-mediated biosynthesis of metallic nanoparticles: A review of literature, factors affecting synthesis, characterization techniques and applications. J. Environ. Chem. Eng. 2017, 5, 4866-4883. [CrossRef]

96. Prasad, R.; Bhattacharyya, A.; Nguyen, Q.D. Nanotechnology in Sustainable Agriculture: Recent Developments, Challenges, and Perspectives. Front. Microbiol. 2017, 8. [CrossRef]

97. Chavan, R.R.; Bhinge, S.D.; Bhutkar, M.A.; Randive, D.S.; Wadkar, G.H.; Todkar, S.S.; Urade, M.N. Characterization, antioxidant, antimicrobial and cytotoxic activities of green synthesized silver and iron nanoparticles using alcoholic Blumea eriantha DC plant extract. Mater. Today Commun. 2020, 24, 101320. [CrossRef]

98. Design of Silver Nanoparticles with Graphene Coatings Layers Used for LSPR Biosensor ApplicationsScienceDirect. Available online: https://www.sciencedirect.com/science/article/abs/pii/S0042207X20303614 (accessed on 8 July 2020).

99. Teodoro, K.B.R.; Shimizu, F.M.; Scagion, V.P.; Correa, D.S. Ternary nanocomposites based on cellulose nanowhiskers, silver nanoparticles and electrospun nanofibers: Use in an electronic tongue for heavy metal detection. Sens. Actuators B Chem. 2019, 290, 387-395. [CrossRef]

100. Giljohann, D.A.; Seferos, D.S.; Daniel, W.L.; Massich, M.D.; Patel, P.C.; Mirkin, C.A. Gold Nanoparticles for Biology and Medicine. Angew. Chem. Int. Ed. 2010, 49, 3280-3294. [CrossRef]

101. Gold Nanoparticles in Biology: Beyond Toxicity to Cellular Imaging | Accounts of Chemical Research. Available online: https://pubs.acs.org/doi/10.1021/ar800035u (accessed on 6 July 2020).

102. Bhattacharya, R.; Mukherjee, P. Biological properties of "naked" metal nanoparticles. Adv. Drug Deliv. Rev. 2008, 60, 1289-1306. [CrossRef]

103. Pardhi, D.M.; Şen Karaman, D.; Timonen, J.; Wu, W.; Zhang, Q.; Satija, S.; Mehta, M.; Charbe, N.; McCarron, P.A.; Tambuwala, M.; et al. Anti-bacterial activity of inorganic nanomaterials and their antimicrobial peptide conjugates against resistant and non-resistant pathogens. Int. J. Pharm. 2020, 586, 119531. [CrossRef]

104. Ali, J.; Ali, N.; Wang, L.; Waseem, H.; Pan, G. Revisiting the mechanistic pathways for bacterial mediated synthesis of noble metal nanoparticles. J. Microbiol. Methods 2019, 159, 18-25. [CrossRef] [PubMed]

105. Nishanthi, R.; Malathi, S.; Palani, P. Green synthesis and characterization of bioinspired silver, gold and platinum nanoparticles and evaluation of their synergistic antibacterial activity after combining with different classes of antibiotics. Mater. Sci. Eng. C 2019, 96, 693-707. [CrossRef]

106. Dutta, T.; Ghosh, N.N.; Das, M.; Adhikary, R.; Mandal, V.; Chattopadhyay, A.P. Green synthesis of antibacterial and antifungal silver nanoparticles using Citrus limetta peel extract: Experimental and theoretical studies. J. Environ. Chem. Eng. 2020, 8, 104019. [CrossRef]

107. Taruna, K.J.; Bhatti, J.; Kumar, P. Green synthesis and physico-chemical study of silver nanoparticles extracted from a natural source Luffa acutangula. J. Mol. Liq. 2016, 224, 991-998. [CrossRef]

108. Ravichandran, V.; Vasanthi, S.; Shalini, S.; Shah, S.A.A.; Tripathy, M.; Paliwal, N. Green synthesis, characterization, antibacterial, antioxidant and photocatalytic activity of Parkia speciosa leaves extract mediated silver nanoparticles. Results Phys. 2019, 15, 102565. [CrossRef]

109. Ahmed, S.; Saifullah; Ahmad, M.; Swami, B.L.; Ikram, S. Green synthesis of silver nanoparticles using Azadirachta indica aqueous leaf extract. J. Radiat. Res. Appl. Sci. 2016, 9, 1-7. [CrossRef]

110. Tamilarasi, P.; Meena, P. Green synthesis of silver nanoparticles (Ag NPs) using Gomphrena globosa (Globe amaranth) leaf extract and their characterization. Mater. Today Proc. 2020. [CrossRef]

111. Anandalakshmi, K.; Venugobal, J.; Ramasamy, V. Characterization of silver nanoparticles by green synthesis method using Pedalium murex leaf extract and their antibacterial activity. Appl. Nanosci. 2016, 6, 399-408. [CrossRef]

112. Ibrahim, H.M.M. Green synthesis and characterization of silver nanoparticles using banana peel extract and their antimicrobial activity against representative microorganisms. J. Radiat. Res. Appl. Sci. 2015, 8, 265-275. [CrossRef] 
113. Manikandakrishnan, M.; Palanisamy, S.; Vinosha, M.; Kalanjiaraja, B.; Mohandoss, S.; Manikandan, R.; Tabarsa, M.; You, S.; Prabhu, N.M. Facile green route synthesis of gold nanoparticles using Caulerpa racemosa for biomedical applications. J. Drug Deliv. Sci. Technol. 2019, 54, 101345. [CrossRef]

114. Vijayakumar, S.; Vinayagam, R.; Anand, M.A.V.; Venkatachalam, K.; Saravanakumar, K.; Wang, M.-H.; Casimeer, C.S.; Km, G.; David, E. Green synthesis of gold nanoparticle using Eclipta alba and its antidiabetic activities through regulation of Bcl-2 expression in pancreatic cell line. J. Drug Deliv. Sci. Technol. 2020, 58, 101786. [CrossRef]

115. Bhau, B.S.; Ghosh, S.; Puri, S.; Borah, B.; Sarmah, D.K.; Khan, R. Green Synthesis of Gold Nanoparticles from The Leaf Extract of Nepenthes Khasiana And Antimicrobial Assay. Adv. Mater. Lett. 2015, 6, 55-58. [CrossRef]

116. Mollick, M.M.R.; Bhowmick, B.; Mondal, D.; Maity, D.; Rana, D.; Dash, S.K.; Chattopadhyay, S.; Roy, S.; Sarkar, J.; Acharya, K.; et al. Anticancer (in vitro) and antimicrobial effect of gold nanoparticles synthesized using Abelmoschus esculentus (L.) pulp extract via a green route. RSC Adv. 2014, 4, 37838-37848. [CrossRef]

117. Mishra, A.; Tripathy, S.K.; Yun, S.-I. Bio-Synthesis of Gold and Silver Nanoparticles from Candida guilliermondii and Their Antimicrobial Effect against Pathogenic Bacteria. J. Nanosci. Nanotechnol. 2011, 11, 243-248. [CrossRef] [PubMed]

118. Yugay, Y.A.; Usoltseva, R.V.; Silant'ev, V.E.; Egorova, A.E.; Karabtsov, A.A.; Kumeiko, V.V.; Ermakova, S.P.; Bulgakov, V.P.; Shkryl, Y.N. Synthesis of bioactive silver nanoparticles using alginate, fucoidan and laminaran from brown algae as a reducing and stabilizing agent. Carbohydr. Polym. 2020, 245, 116547. [CrossRef]

119. Islam, N.U.; Jalil, K.; Shahid, M.; Rauf, A.; Muhammad, N.; Khan, A.; Shah, M.R.; Khan, M.A. Green synthesis and biological activities of gold nanoparticles functionalized with Salix alba. Arab. J. Chem. 2019, 12, 2914-2925. [CrossRef]

120. Rashmi, B.N.; Harlapur, S.F.; Avinash, B.; Ravikumar, C.R.; Nagaswarupa, H.P.; Anil Kumar, M.R.; Gurushantha, K.; Santosh, M.S. Facile green synthesis of silver oxide nanoparticles and their electrochemical, photocatalytic and biological studies. Inorg. Chem. Commun. 2020, 111, 107580. [CrossRef]

121. Nadeem, M.; Abbasi, B.H.; Younas, M.; Ahmad, W.; Khan, T. A review of the green syntheses and anti-microbial applications of gold nanoparticles. Green Chem. Lett. Rev. 2017, 10, 216-227. [CrossRef]

122. Ahmad, A.; Syed, F.; Imran, M.; Khan, A.U.; Tahir, K.; Khan, Z.U.H.; Yuan, Q. Phytosynthesis and Antileishmanial Activity of Gold Nanoparticles by Maytenus Royleanus. J. Food Biochem. 2016, 40, 420-427. [CrossRef]

123. Cui, Y.; Zhao, Y.; Tian, Y.; Zhang, W.; Lü, X.; Jiang, X. The molecular mechanism of action of bactericidal gold nanoparticles on Escherichia coli. Biomaterials 2012, 33, 2327-2333. [CrossRef]

124. Chauhan, R.; Kumar, A.; Abraham, J. A Biological Approach to the Synthesis of Silver Nanoparticles with Streptomyces sp JAR1 and its Antimicrobial Activity. Sci. Pharm. 2013, 81, 607-624. [CrossRef] [PubMed]

125. Manivasagan, P.; Venkatesan, J.; Senthilkumar, K.; Sivakumar, K.; Kim, S.-K. Biosynthesis, Antimicrobial and Cytotoxic Effect of Silver Nanoparticles Using a Novel Nocardiopsis sp. MBRC-1. Available online: https://www.hindawi.com/journals/bmri/2013/287638/ (accessed on 29 July 2020).

126. Franci, G.; Falanga, A.; Galdiero, S.; Palomba, L.; Rai, M.; Morelli, G.; Galdiero, M. Silver Nanoparticles as Potential Antibacterial Agents. Molecules 2015, 20, 8856-8874. [CrossRef] [PubMed]

127. Muthuvel, A.; Adavallan, K.; Balamurugan, K.; Krishnakumar, N. Biosynthesis of gold nanoparticles using Solanum nigrum leaf extract and screening their free radical scavenging and antibacterial properties. Biomed. Prev. Nutr. 2014, 4, 325-332. [CrossRef]

128. Kaviya, S.; Santhanalakshmi, J.; Viswanathan, B.; Muthumary, J.; Srinivasan, K. Biosynthesis of silver nanoparticles using citrus sinensis peel extract and its antibacterial activity. Spectrochim. Acta. A. Mol. Biomol. Spectrosc. 2011, 79, 594-598. [CrossRef]

129. Nirmala Grace, A.; Pandian, K. Antibacterial efficacy of aminoglycosidic antibiotics protected gold nanoparticles-A brief study. Colloids Surf. Physicochem. Eng. Asp. 2007, 297, 63-70. [CrossRef]

130. Padalia, H.; Moteriya, P.; Chanda, S. Green synthesis of silver nanoparticles from marigold flower and its synergistic antimicrobial potential. Arab. J. Chem. 2015, 8, 732-741. [CrossRef]

131. Wang, Y.-W.; Tang, H.; Wu, D.; Liu, D.; Liu, Y.; Cao, A.; Wang, H. Enhanced bactericidal toxicity of silver nanoparticles by the antibiotic gentamicin. Environ. Sci. Nano 2016, 3, 788-798. [CrossRef]

132. Chang, Q.; Wang, W.; Regev-Yochay, G.; Lipsitch, M.; Hanage, W.P. Antibiotics in agriculture and the risk to human health: How worried should we be? Evol. Appl. 2015, 8, 240-247. [CrossRef] 
133. Ramesh, A.; Tamizhdurai, P.; Gopinath, S.; Sureshkumar, K.; Murugan, E.; Shanthi, K. Facile synthesis of core-shell nanocomposites Au catalysts towards abatement of environmental pollutant Rhodamine B. Heliyon 2019, 5, e01005. [CrossRef] [PubMed]

134. Thangamani, N.; Bhuvaneshwari, N. Green synthesis of gold nanoparticles using Simarouba glauca leaf extract and their biological activity of micro-organism. Chem. Phys. Lett. 2019, 732, 136587. [CrossRef]

135. Annamalai, A.; Christina, V.L.P.; Sudha, D.; Kalpana, M.; Lakshmi, P.T.V. Green synthesis, characterization and antimicrobial activity of Au NPs using Euphorbia hirta L. leaf extract. Colloids Surf. B Biointerfaces 2013, 108, 60-65. [CrossRef] [PubMed]

136. Folorunso, A.; Akintelu, S.; Oyebamiji, A.K.; Ajayi, S.; Abiola, B.; Abdusalam, I.; Morakinyo, A. Biosynthesis, characterization and antimicrobial activity of gold nanoparticles from leaf extracts of Annona muricata. J. Nanostruct. Chem. 2019, 9, 111-117. [CrossRef]

137. Montes de Oca-Vásquez, G.; Solano-Campos, F.; Vega-Baudrit, J.R.; López-Mondéjar, R.; Odriozola, I.; Vera, A.; Moreno, J.L.; Bastida, F. Environmentally relevant concentrations of silver nanoparticles diminish soil microbial biomass but do not alter enzyme activities or microbial diversity. J. Hazard. Mater. 2020, 391, 122224. [CrossRef] [PubMed]

138. Nie, X.; Zhu, K.; Zhao, S.; Dai, Y.; Tian, H.; Sharma, V.K.; Jia, H. Interaction of Ag+ with soil organic matter: Elucidating the formation of silver nanoparticles. Chemosphere 2020, 243, 125413. [CrossRef] [PubMed]

139. Lediga, M.E.; Malatjie, T.S.; Olivier, D.K.; Ndinteh, D.T.; van Vuuren, S.F. Biosynthesis and characterisation of antimicrobial silver nanoparticles from a selection of fever-reducing medicinal plants of South Africa. South Afr. J. Bot. 2018, 119, 172-180. [CrossRef]

140. Shahryari, F.; Rabiei, Z.; Sadighian, S. Antibacterial activity of synthesized silver nanoparticles by sumac aqueous extract and silver-chitosan nanocomposite against Pseudomonas syringae pv. syringae. J. Plant Pathol. 2020, 102, 469-475. [CrossRef]

141. Jebril, S.; Khanfir Ben Jenana, R.; Dridi, C. Green synthesis of silver nanoparticles using Melia azedarach leaf extract and their antifungal activities: In vitro and in vivo. Mater. Chem. Phys. 2020, 248, 122898. [CrossRef]

142. Balasubramanian, S.; Kala, S.M.J.; Pushparaj, T.L. Biogenic synthesis of gold nanoparticles using Jasminum auriculatum leaf extract and their catalytic, antimicrobial and anticancer activities. J. Drug Deliv. Sci. Technol. 2020, 57, 101620. [CrossRef]

143. Bumbudsanpharoke, N.; Ko, S. Nano-Food Packaging: An Overview of Market, Migration Research, and Safety Regulations. J. Food Sci. 2015, 80, R910-R923. Available online: https://onlinelibrary.wiley.com/doi/ full/10.1111/1750-3841.12861 (accessed on 30 July 2020). [CrossRef]

144. Berekaa, M.M. Nanotechnology in Food Industry; Advances in Food processing, Packaging and Food Safety. Int. J. Curr. Microbiol. App. Sci. 2015, 4, 345-357.

145. Omara, A.E.-D.; Elsakhawy, T.; Alshaal, T.; El-Ramady, H.; Kovács, Z.; Fári, M. Nanoparticles: A Novel Approach for Sustainable Agro-productivity. Environ. Biodivers. Soil Secur. 2019, 3, 29-62. [CrossRef]

146. Fernández-Luqueño, F.; Medina-Pérez, G.; López-Valdez, F.; Gutiérrez-Ramírez, R.; Campos-Montiel, R.G.; Vázquez-Núñez, E.; Loera-Serna, S.; Almaraz-Buendía, I.; Del Razo-Rodríguez, O.E.; Madariaga-Navarrete, A. Use of Agronanobiotechnology in the Agro-Food Industry to Preserve Environmental Health and Improve the Welfare of Farmers. In Agricultural Nanobiotechnology: Modern Agriculture for a Sustainable Future; López-Valdez, F., Fernández-Luqueño, F., Eds.; Springer International Publishing: Cham, Switzerland, 2018; pp. 3-16. ISBN 978-3-319-96719-6.

147. Graily-Moradi, F.; Maadani Mallak, A.; Ghorbanpour, M. Biogenic Synthesis of Gold Nanoparticles and Their Potential Application in Agriculture. In Biogenic Nano-Particles and Their Use in Agro-Ecosystems; Ghorbanpour, M., Bhargava, P., Varma, A., Choudhary, D.K., Eds.; Springer: Singapore, 2020; pp. 187-204. ISBN 9789811529856.

148. Palit, S.; Hussain, C.M. Chapter 1-Functionalization of nanomaterials for industrial applications: Recent and future perspectives. In Handbook of Functionalized Nanomaterials for Industrial Applications; Mustansar Hussain, C., Ed.; Micro and Nano Technologies; Elsevier: Amsterdam, The Netherlands, 2020; pp. 3-14. ISBN 978-0-12-816787-8.

149. Dobrucka, R. Metal nanoparticles in nanosensors for food qualityassurance. LogForum 2020, 16. [CrossRef]

150. Vinci, G.; Rapa, M. Noble Metal Nanoparticles Applications: Recent Trends in Food Control. Bioengineering 2019, 6, 10. [CrossRef] 
151. Sheng, Z.; Liu, Y. Effects of silver nanoparticles on wastewater biofilms. Water Res. 2011, 45, 6039-6050. [CrossRef]

152. Manimegalai, G.; Kumar, S.S.; Sharma, C. Pesticide Mineralization in Water Using Silver Nanoparticles. Int. J. Chem. Sci. 2011, 9, 1463-1471.

153. Saifuddin, N.; Nian, C.Y.; Zhan, L.W.; Ning, K.X. Chitosan-silver Nanoparticles Composite as Point-of-use Drinking Water Filtration System for Household to Remove Pesticides in Water. Asian J. Biochem. 2011, 6 , 142-159. [CrossRef]

154. Sushma, D.; Richa, S. Use of Nanoparticles in Water Treatment: A review. Int. Res. J. Environ. Sci. 2015, 4, 103-106.

155. Morsi, R.E.; Alsabagh, A.M.; Nasr, S.A.; Zaki, M.M. Multifunctional nanocomposites of chitosan, silver nanoparticles, copper nanoparticles and carbon nanotubes for water treatment: Antimicrobial characteristics. Int. J. Biol. Macromol. 2017, 97, 264-269. [CrossRef]

156. Francis, S.; Joseph, S.; Koshy, E.P.; Mathew, B. Green synthesis and characterization of gold and silver nanoparticles using Mussaenda glabrata leaf extract and their environmental applications to dye degradation. Environ. Sci. Pollut. Res. 2017, 24, 17347-17357. [CrossRef]

157. Veisi, H.; Azizi, S.; Mohammadi, P. Green synthesis of the silver nanoparticles mediated by Thymbra spicata extract and its application as a heterogeneous and recyclable nanocatalyst for catalytic reduction of a variety of dyes in water. J. Clean. Prod. 2018, 170, 1536-1543. [CrossRef]

158. Saratale, R.G.; Saratale, G.D.; Shin, H.S.; Jacob, J.M.; Pugazhendhi, A.; Bhaisare, M.; Kumar, G. New insights on the green synthesis of metallic nanoparticles using plant and waste biomaterials: Current knowledge, their agricultural and environmental applications. Environ. Sci. Pollut. Res. 2018, 25, 10164-10183. [CrossRef] [PubMed]

159. Chaudhry, N.; Dwivedi, S.; Chaudhry, V.; Singh, A.; Saquib, Q.; Azam, A.; Musarrat, J. Bio-inspired nanomaterials in agriculture and food: Current status, foreseen applications and challenges. Microb. Pathog. 2018, 123, 196-200. [CrossRef]

160. Peters, R.J.B.; Bouwmeester, H.; Gottardo, S.; Amenta, V.; Arena, M.; Brandhoff, P.; Marvin, H.J.P.; Mech, A.; Moniz, F.B.; Pesudo, L.Q.; et al. Nanomaterials for products and application in agriculture, feed and food. Trends Food Sci. Technol. 2016, 54, 155-164. [CrossRef]

161. Kah, M. Nanopesticides and Nanofertilizers: Emerging Contaminants or Opportunities for Risk Mitigation? Front Chem. 2015, 3. [CrossRef] [PubMed]

162. Martínez-Fernández, D.; Barroso, D.; Komárek, M. Root water transport of Helianthus annuus L. under iron oxide nanoparticle exposure. Environ. Sci. Pollut. Res. 2016, 23, 1732-1741. [CrossRef] [PubMed]

163. Kang, H.; Hwang, Y.-G.; Lee, T.-G.; Jin, C.-R.; Cho, C.H.; Jeong, H.-Y.; Kim, D.-O. Use of Gold Nanoparticle Fertilizer Enhances the Ginsenoside Contents and Anti-Inflammatory Effects of Red Ginseng. J. Microbiol. Biotechnol. 2016, 26, 1668-1674. [CrossRef] [PubMed]

164. Solanki, P.; Bhargava, A.; Chhipa, H.; Jain, N.; Panwar, J. Nano-fertilizers and Their Smart Delivery System. In Nanotechnologies in Food and Agriculture; Rai, M., Ribeiro, C., Mattoso, L., Duran, N., Eds.; Springer International Publishing: Cham, Switzerland, 2015; pp. 81-101. ISBN 978-3-319-14024-7.

165. Panpatte, D.G.; Jhala, Y.K.; Shelat, H.N.; Vyas, R.V. Nanoparticles: The Next Generation Technology for Sustainable Agriculture. In Microbial Inoculants in Sustainable Agricultural Productivity: Vol. 2: Functional Applications; Singh, D.P., Singh, H.B., Prabha, R., Eds.; Springer India: New Delhi, India, 2016; pp. 289-300. ISBN 978-81-322-2644-4.

166. Nanoencapsulation, Nano-Guard for Pesticides: A New Window for Safe Application | Journal of Agricultural and Food Chemistry. Available online: https://pubs.acs.org/doi/abs/10.1021/acs.jafc.5b05214? casa_token=cRnbfVrk4PoAAAAA:7xYcayZ3S03ryq1w2J3jTElTsb-bo7fn-1ywuBl2z6RVF7RcZGkEK8aaJcBjYhRgzoenykGwpteCsZI (accessed on 30 July 2020).

167. Alghuthaymi, M.A.; Almoammar, H.; Rai, M.; Said-Galiev, E.; Abd-Elsalam, K.A. Myconanoparticles: Synthesis and their role in phytopathogens management. Biotechnol. Biotechnol. Equip. 2015, 29, 221-236. [CrossRef]

168. Biosynthesis of Silver Nanoparticles Using Fusarium Solaniand Its Impact on Grainborne Fungi. Available online: http://chalcogen.ro/655_AbdElAziz.pdf (accessed on 30 July 2020). 
169. Gnanadesigan, M.; Anand, M.; Ravikumar, S.; Maruthupandy, M.; Vijayakumar, V.; Selvam, S.; Dhineshkumar, M.; Kumaraguru, A. Biosynthesis of silver nanoparticles by using mangrove plant extract and their potential mosquito larvicidal property. Asian Pac. J. Trop. Med. 2011, 4, 799-803. [CrossRef]

170. Liu, R.; Lal, R. Potentials of engineered nanoparticles as fertilizers for increasing agronomic productions. Sci. Total Environ. 2015, 514, 131-139. [CrossRef]

171. Prabhu, S.; Poulose, E.K. Silver nanoparticles: Mechanism of antimicrobial action, synthesis, medical applications, and toxicity effects. Int. Nano Lett. 2012, 2, 32. [CrossRef]

172. Jorge de Souza, T.A.; Rosa Souza, L.R.; Franchi, L.P. Silver nanoparticles: An integrated view of green synthesis methods, transformation in the environment, and toxicity. Ecotoxicol. Environ. Saf. 2019, 171, 691-700. [CrossRef]

173. Li, N.; Zhao, P.; Astruc, D. Anisotropic Gold Nanoparticles: Synthesis, Properties, Applications, and Toxicity. Angew. Chem. Int. Ed. 2014, 53, 1756-1789. [CrossRef]

174. Patil, S.S.; Shedbalkar, U.U.; Truskewycz, A.; Chopade, B.A.; Ball, A.S. Nanoparticles for environmental clean-up: A review of potential risks and emerging solutions. Environ. Technol. Innov. 2016, 5, 10-21. [CrossRef]

175. Singh, A.; Singh, N.B.; Hussain, I.; Singh, H.; Singh, S.C. Plant-nanoparticle interaction: An approach to improve agricultural practices and plant productivity. Int. J. Pharm. Sci. Invent. 2015, 4, 25-40.

176. Singh, S.; Vishwakarma, K.; Singh, S.; Sharma, S.; Dubey, N.K.; Singh, V.K.; Liu, S.; Tripathi, D.K.; Chauhan, D.K. Understanding the plant and nanoparticle interface at transcriptomic and proteomic level: A concentric overview. Plant Gene 2017, 11, 265-272. [CrossRef]

177. Ma, X.; Geiser-Lee, J.; Deng, Y.; Kolmakov, A. Interactions between engineered nanoparticles (ENPs) and plants: Phytotoxicity, uptake and accumulation. Sci. Total Environ. 2010, 408, 3053-3061. [CrossRef] [PubMed]

178. Tripathi, D.K.; Tripathi, A.; Shweta; Singh, S.; Singh, Y.; Vishwakarma, K.; Yadav, G.; Sharma, S.; Singh, V.K.; Mishra, R.K.; et al. Uptake, Accumulation and Toxicity of Silver Nanoparticle in Autotrophic Plants, and Heterotrophic Microbes: A Concentric Review. Front. Microbiol. 2017, 8. [CrossRef]

179. Judy, J.D.; Unrine, J.M.; Rao, W.; Wirick, S.; Bertsch, P.M. Bioavailability of Gold Nanomaterials to Plants: Importance of Particle Size and Surface Coating. Environ. Sci. Technol. 2012, 46, 8467-8474. [CrossRef] [PubMed]

180. Hashimoto, Y.; Takeuchi, S.; Mitsunobu, S.; Ok, Y.-S. Chemical speciation of silver (Ag) in soils under aerobic and anaerobic conditions: Ag nanoparticles vs. ionic Ag. J. Hazard. Mater. 2017, 322, 318-324. [CrossRef]

181. Mirzajani, F.; Askari, H.; Hamzelou, S.; Schober, Y.; Römpp, A.; Ghassempour, A.; Spengler, B. Proteomics study of silver nanoparticles toxicity on Oryza sativa L. Ecotoxicol. Environ. Saf. 2014, 108, 335-339. [CrossRef]

182. Morphological and Proteomic Responses of Eruca Sativa Exposed to Silver Nanoparticles or Silver Nitrate. Available online: https://journals.plos.org/plosone/article?id=10.1371/journal.pone.0068752 (accessed on 30 July 2020).

183. Kaveh, R.; Li, Y.-S.; Ranjbar, S.; Tehrani, R.; Brueck, C.L.; Van Aken, B. Changes in Arabidopsis thaliana Gene Expression in Response to Silver Nanoparticles and Silver Ions. Environ. Sci. Technol. 2013, 47, 10637-10644. [CrossRef] [PubMed]

184. Taylor, A.F.; Rylott, E.L.; Anderson, C.W.N.; Bruce, N.C. Investigating the Toxicity, Uptake, Nanoparticle Formation and Genetic Response of Plants to Gold. PLoS ONE 2014, 9, e93793. [CrossRef] [PubMed]

185. Raliya, R.; Franke, C.; Chavalmane, S.; Nair, R.; Reed, N.; Biswas, P. Quantitative Understanding of Nanoparticle Uptake in Watermelon Plants. Front. Plant Sci. 2016, 7. [CrossRef]

186. Qian, H.; Peng, X.; Han, X.; Ren, J.; Sun, L.; Fu, Z. Comparison of the toxicity of silver nanoparticles and silver ions on the growth of terrestrial plant model Arabidopsis thaliana. J. Environ. Sci. 2013, 25, 1947-1956. [CrossRef]

187. Stampoulis, D.; Sinha, S.K.; White, J.C. Assay-Dependent Phytotoxicity of Nanoparticles to Plants. Environ. Sci. Technol. 2009, 43, 9473-9479. [CrossRef]

188. El-Temsah, Y.S.; Joner, E.J. Impact of Fe and Ag nanoparticles on seed germination and differences in bioavailability during exposure in aqueous suspension and soil. Environ. Toxicol. 2012, 27, 42-49. [CrossRef]

189. Hao, Y.; Zhang, Z.; Rui, Y.; Ren, J.; Hou, T.; Wu, S.; Rui, M.; Jiang, F.; Liu, L. Effect of Different Nanoparticles on Seed Germination and Seedling Growth in Rice. In 2nd Annual International Conference on Advanced Material Engineering; Atlantis Press: Paris, France, 2016; pp. 166-173. 
190. Courtois, P.; Rorat, A.; Lemiere, S.; Guyoneaud, R.; Attard, E.; Levard, C.; Vandenbulcke, F. Ecotoxicology of silver nanoparticles and their derivatives introduced in soil with or without sewage sludge: A review of effects on microorganisms, plants and animals. Environ. Pollut. 2019, 253, 578-598. [CrossRef]

191. Dinesh, R.; Anandaraj, M.; Srinivasan, V.; Hamza, S. Engineered nanoparticles in the soil and their potential implications to microbial activity. Geoderma 2012, 173, 19-27. [CrossRef]

192. Mishra, S.; Yang, X.; Singh, H.B. Evidence for positive response of soil bacterial community structure and functions to biosynthesized silver nanoparticles: An approach to conquer nanotoxicity? J. Environ. Manag. 2020, 253, 109584. [CrossRef]

193. Eivazi, F.; Afrasiabi, Z.; Jose, E. Effects of Silver Nanoparticles on the Activities of Soil Enzymes Involved in Carbon and Nutrient Cycling. Pedosphere 2018, 28, 209-214. [CrossRef]

194. Hänsch, M.; Emmerling, C. Effects of silver nanoparticles on the microbiota and enzyme activity in soil. J. Plant Nutr. Soil Sci. 2010, 173, 554-558. [CrossRef]

195. Shin, Y.-J.; Kwak, J.I.; An, Y.-J. Evidence for the inhibitory effects of silver nanoparticles on the activities of soil exoenzymes. Chemosphere 2012, 88, 524-529. [CrossRef] [PubMed]

196. Peyrot, C.; Wilkinson, K.J.; Desrosiers, M.; Sauvé, S. Effects of silver nanoparticles on soil enzyme activities with and without added organic matter. Environ. Toxicol. Chem. 2014, 33, 115-125. [CrossRef] [PubMed]

197. González-Fuenzalida, R.A.; Sanjuan-Navarro, L.; Moliner-Martínez, Y.; Campíns-Falcó, P. Quantitative study of the capture of silver nanoparticles by several kinds of soils. Sci. Total Environ. 2018, 630, 1226-1236. [CrossRef] [PubMed]

198. Grün, A.-L.; Straskraba, S.; Schulz, S.; Schloter, M.; Emmerling, C. Long-term effects of environmentally relevant concentrations of silver nanoparticles on microbial biomass, enzyme activity, and functional genes involved in the nitrogen cycle of loamy soil. J. Environ. Sci. 2018, 69, 12-22. [CrossRef]

199. Rahmatpour, S.; Shirvani, M.; Mosaddeghi, M.R.; Nourbakhsh, F.; Bazarganipour, M. Dose-response effects of silver nanoparticles and silver nitrate on microbial and enzyme activities in calcareous soils. Geoderma 2017, 285, 313-322. [CrossRef]

200. McGee, C.F.; Storey, S.; Clipson, N.; Doyle, E. Soil microbial community responses to contamination with silver, aluminium oxide and silicon dioxide nanoparticles. Ecotoxicology 2017, 26, 449-458. [CrossRef]

201. Grün, A.-L.; Manz, W.; Kohl, Y.L.; Meier, F.; Straskraba, S.; Jost, C.; Drexel, R.; Emmerling, C. Impact of silver nanoparticles (AgNP) on soil microbial community depending on functionalization, concentration, exposure time, and soil texture. Environ. Sci. Eur. 2019, 31, 15. [CrossRef]

202. Ashish; Singh, D.; Gupta, N. Impact of Nanoparticles on PGPR and Soil Nutrient Contents. In Biogenic Nano-Particles and their Use in Agro-ecosystems; Ghorbanpour, M., Bhargava, P., Varma, A., Choudhary, D.K., Eds.; Springer: Singapore, 2020; pp. 247-257. ISBN 9789811529856.

203. Unrine, J.M.; Hunyadi, S.E.; Tsyusko, O.V.; Rao, W.; Shoults-Wilson, W.A.; Bertsch, P.M. Evidence for Bioavailability of Au Nanoparticles from Soil and Biodistribution within Earthworms (Eisenia fetida). Environ. Sci. Technol. 2010, 44, 8308-8313. [CrossRef]

204. Gold and Silver Nanoparticles Effects to the Earthworm Eisenia Fetida-The Importance of Tissue Over Soil Concentrations: Drug and Chemical Toxicology: Vol 0, No 0. Available online: https://www.tandfonline. com/doi/abs/10.1080/01480545.2019.1567757 (accessed on 30 July 2020).

205. Schlich, K.; Klawonn, T.; Terytze, K.; Hund-Rinke, K. Effects of silver nanoparticles and silver nitrate in the earthworm reproduction test. Environ. Toxicol. Chem. 2013, 32, 181-188. [CrossRef]

206. van der Ploeg, M.J.C.; Handy, R.D.; Waalewijn-Kool, P.L.; van den Berg, J.H.J.; Herrera Rivera, Z.E.; Bovenschen, J.; Molleman, B.; Baveco, J.M.; Tromp, P.; Peters, R.J.B.; et al. Effects of silver nanoparticles (NM-300K) on Lumbricus rubellus earthworms and particle characterization in relevant test matrices including soil: Silver nanoparticles affect Lumbricus rubellus earthworms. Environ. Toxicol. Chem. 2014, 33, 743-752. [CrossRef] [PubMed]

207. Tourinho, P.S.; van Gestel, C.A.M.; Lofts, S.; Svendsen, C.; Soares, A.M.V.M.; Loureiro, S. Metal-based nanoparticles in soil: Fate, behavior, and effects on soil invertebrates. Environ. Toxicol. Chem. 2012, 31, 1679-1692. [CrossRef] [PubMed]

208. El Hadri, H.; Louie, S.M.; Hackley, V.A. Assessing the interactions of metal nanoparticles in soil and sediment matrices-A quantitative analytical multi-technique approach. Environ. Sci. Nano 2018, 5, $203-214$. [CrossRef] 
209. Meier, M.J.; Dodge, A.E.; Samarajeewa, A.D.; Beaudette, L.A. Soil exposed to silver nanoparticles reveals significant changes in community structure and altered microbial transcriptional profiles. Environ. Pollut. 2020, 258, 113816. [CrossRef]

210. Asadishad, B.; Chahal, S.; Akbari, A.; Cianciarelli, V.; Azodi, M.; Ghoshal, S.; Tufenkji, N. Amendment of Agricultural Soil with Metal Nanoparticles: Effects on Soil Enzyme Activity and Microbial Community Composition. Environ. Sci. Technol. 2018, 52, 1908-1918. [CrossRef]

211. Li, M.; Greenfield, B.K.; Nunes, L.M.; Dang, F.; Liu, H.; Zhou, D.; Yin, B. High retention of silver sulfide nanoparticles in natural soils. J. Hazard. Mater. 2019, 378, 120735. [CrossRef] [PubMed]

(C) 2020 by the authors. Licensee MDPI, Basel, Switzerland. This article is an open access article distributed under the terms and conditions of the Creative Commons Attribution (CC BY) license (http://creativecommons.org/licenses/by/4.0/). 